\title{
Maritime Piracy and the Impunity Gap: Insufficient National Laws or a Lack of Political Will?
}

\author{
Yvonne M. Dutton*
}

\begin{abstract}
Nations are not prosecuting piracy suspects with any regularity. One reason cited for this culture of impunity is the lack of domestic legislation to facilitate the prosecution of suspected pirates. However, universal jurisdiction over piracy has existed for more than one hundred years, and most nations are parties to the United Nations Convention on the Law of the Sea (UNCLOS) and the Convention for the Suppression of Unlawful Acts Against the Safety of Maritime Navigation (SUA Convention), both of which encourage nations to cooperate in prosecuting acts of maritime piracy. Given this legal framework, should we not expect that nations would have domestic laws criminalizing piracy and would use those laws to try the pirates they have gone to such lengths to capture? This Article explores these questions by examining the domestic antipiracy laws in about fifty states for which information is available in English. The analysis supports a conclusion that on the whole states lack the political will to share in the burden of prosecuting pirates because relatively few states have enacted comprehensive antipiracy laws that include a framework for exercising universal jurisdiction over pirate attacks. The analysis also shows that the laws states have enacted may not be sufficient to allow for a successful prosecution for today's pirates. Although states may have many reasons to sit back and wait for others to prosecute maritime piracy offenses, this Article concludes that all states must embrace their duty to share in the burden of prosecuting pirates, which means that all states must first pass the necessary domestic laws criminalizing maritime piracy.
\end{abstract}

I. INTRODUCTION 1112

II. THE INTERNATIONAL LEGAL FRAMEWORK GOVERNING THE CRIME OF PIRACY

A. Universal Jurisdiction.

B. UNCLOS's Piracy Provisions

C. The SUA Convention's Piracy Provisions

III. THE PIRACY THREAT AND THE RESPONSE OF THE INTERNATIONAL COMMUNITY

A. The Maritime Piracy Problem

B. Coordinated Antipiracy Naval Operations and the Security Council Resolutions Authorizing and Encouraging Antipiracy Operations....

* C 2012 Yvonne M. Dutton. Faculty, University of San Diego School of Law; J.D. Columbia Law School; Ph.D., Political Science, University of Colorado at Boulder. I wish to thank the University of San Diego School of Law for providing a summer research grant to support this project. For research assistance, I thank Kian Meshkat.

1111 
C. Nations'Reluctance To Prosecute Captured Pirates and the General Culture of Impunity.

IV. NaTiOnal LaWs CRIMINALIZING ACTS OF PirACY: AN

OVERVIEW

A. States Defining Piracy According to the Law of

Nations

B. States That Directly Incorporate International Treaty

Commitments

C. States Defining Piracy as a Separate Offense with a Framework for Exercising Universal Jurisdiction.

1. States with Laws That at Least Partially

Implement UNCLOS's Piracy Provisions

2. States with Laws That Define Piracy Without

Following UNCLOS's Definition

D. States Defining Piracy Without a Framework for

Exercising Universal Jurisdiction

E. States Relying on General Criminal Laws Without a

Framework for Exercising Universal Jurisdiction.

V. AN ANALYSIS OF WHETHER THE VARIOUS TYPES OF

NATIONAL LAWS ARE SUFFICIENT To SUCCESSFUlLY

PROSECUTE ACTS OF MODERN PIRACY

A. The Potential Difficulties with an Antipiracy Law

That Refers Only to the Law of Nations.

B. The Potential Difficulties with National Laws That Incorporate International Treaties Without

Specifically Defining the Offense of Piracy

C. The Potential Difficulties with National Laws That

Define Piracy According to UNCLOS.

D. The Potential Difficulties with National Laws That

Require a Nexus Between the State and the Offense.

VI. CONCLUSION

\section{INTRODUCTION}

The number of maritime piracy attacks is spiraling ever upward, pirates are increasingly using violence to carry out their attacks, and pirates are demanding more money for the safe release of their captives. Between 2006 and 2010, the number of yearly pirate attacks reported to the International Maritime Bureau (IMB) almost doubled. ${ }^{1}$

1. The International Maritime Bureau (IMB) is a nonprofit organization organized under the International Chamber of Commerce (ICC) and established in 1981 with the goal 
Pirates attacked 239 ships in 2006, increasing to 445 ships in $2010{ }^{2}$ Not only did they attack ships, but also in 2010, pirates took hostage an unprecedented 1181 seafarers -8 of whom were murdered. ${ }^{3}$ The year 2011 brought even worse news: in only the first quarter, pirates murdered 7 crew members and injured 34. Also troubling is the fact that maritime pirates are getting paid huge sums for their violent activities. Some estimates now put the average ransom paid to pirates between US\$2 million and US\$3 million. ${ }^{4}$ The individual pirates who share those ransom payments can take home tens of thousands of dollars as their reward for participating in the capture of a ship and its crew. $^{5}$

of acting as a focal point in the fight against maritime crime and malpractice. International Maritime Bureau, ICC COM. CRIME SERVICES, http://www.icc-ccs.org/index.php (last visited Apr. 17, 2012). In 1992, the IMB opened its Piracy Reporting Centre in Kuala Lumpur, Malaysia, to which seafarers are encouraged to report actual or attempted attacks. INT'L Chamber of Commerce [ICC] Int'l Mar. Bureau [IMB], Piracy and Armed RobBery Against Ships, ANNUAL Report: 1 JANUARY - 31 DeCEMBer 2010, at 5-6, 23 (2011) [hereinafter ICC-IMB 2010 REPORT], available at http://www.simsl.com/Downloads/Piracy/ IMBPiracyReport2010.pdf; IMB Piracy Reporting Centre, ICC COM. CRIME SERVICES, http://www.icc-ccs.org/piracy-reporting-centre (last visited Apr. 17, 2012). The IMB annual reports include acts of piracy and acts of armed robbery against ships, as well as attempts of the same. The IMB's definition of piracy includes illegal acts of violence against a ship traveling on the high seas or any act of inciting the same. See ICC-IMB 2010 REPORT, supra, at 3. The IMB's definition of armed robbery against ships includes acts of violence — or any act of inciting an act of violence - against a ship located within "a State's internal waters, archipelagic waters and territorial sea." Id.

2. Id. at 5-6, 23. The true number of actual and reported pirate attacks is likely much higher, as it is generally believed that shipping companies have incentives to underreport. See Eugene Kontorovich \& Steven Art, An Empirical Examination of Universal Jurisdiction for Piracy, 104 AM. J. INT'L L. 436, 440-41 (2010). In that regard, a recent study by the British House of Commons Transport Committee concluded that between twenty-five percent and fifty percent of maritime piracy crimes may go unreported. James Kraska \& Brian Wilson, The Pirates of the Gulf of Aden: The Coalition Is the Strategy, 45 STAN. J. INT'L L. 243, 257 (2009).

3. ICC-IMB 2010 REPORT, supra note 1, at 23.

4. See Scott Baldauf, Pirates, Inc.: Inside the Booming Somali Business, CHRISTIAN SCI. Monitor (May 31, 2009), http://www.csmonitor.com/World/Africa/2009/0531/p06s03woaf.html. Indeed, according to a One Earth Future Foundation study, the average ransom payment rose from US\$150,000 in 2005 to about US\$5.4 million in 2010. Viola Gienger, Pirates Sell Shares To Buy Boats, Equipment for Attacks, SeAtTle Times (Apr. 22, 2011), $\mathrm{http}: / /$ seattletimes.nwsource.com/html/nationworld/2014851606_piracy23.html. Certain ransoms paid to Somali pirates, however, significantly exceed those averages. For example, in November 2010, a band of pirates received about US\$10 million to release a South Korean supertanker, the SAMHO DREAM. Jeffrey Gettleman, Money in Piracy Attracts More Somalis, N.Y. TIMES, Nov. 10, 2010, at A10.

5. See, e.g., INT'L EXPERT GrP. ON Piracy OfF THE SOMAli COAST, PIRACy OfF THE SOMALI COAST 17 (2008) (reporting that an armed pirate can earn between US\$6000 and US $\$ 10,000$ for a single hijacking yielding a US\$1 million ransom); A Pirate's Life Is Good in Somalia, WASH. TIMES (Dec. 17, 2009), http://www.washingtontimes.com/news/2009/dec/17/ in-somalia-a-pirates-life-for-me/?page=all (stating that pirates tend to receive tens of 
Table 1: Pirate Attacks 2006-2010

\begin{tabular}{|l|c|c|c|c|c|}
\hline & 2006 & 2007 & 2008 & 2009 & 2010 \\
\hline $\begin{array}{l}\text { Number of } \\
\text { Actual and } \\
\begin{array}{l}\text { Attempted } \\
\text { Attacks }\end{array}\end{array}$ & 239 & 263 & 293 & 410 & 455 \\
\hline $\begin{array}{l}\text { Number of } \\
\text { Ships Fired } \\
\text { Upon }\end{array}$ & 7 & 14 & 46 & 121 & 107 \\
\hline $\begin{array}{l}\text { Number of } \\
\text { Hostages Taken }\end{array}$ & 188 & 292 & 889 & 1050 & 1181 \\
\hline
\end{tabular}

Source: ICC-IMB 2010 Report

This is a discouraging trend, especially because over the last several years nations have spent billions of dollars to support naval fleets that patrol pirate-infested waters with the goal of repressing piracy. ${ }^{6}$ While these naval fleets have thwarted some attacks and captured some pirates, the evidence about the increasing frequency of maritime piracy attacks suggests that the full deterrent effect of these naval resources is not being realized. Although the navies have captured pirates, the vast majority of alleged pirates are thereafter released and allowed to continue their illegal activities. ${ }^{7}$ Indeed, a culture of impunity reigns: some nine out of ten pirates are not actually prosecuted. ${ }^{8}$ Thus, pirates

thousands of dollars each from the ransom monies paid); Gettleman, supra note 4 (stating that gunmen participating in the attack of the SAMHO DREAM received some US\$150,000 each).

6. See, e.g., Lauren Ploch et al., Cong. Research Serv., R40528, Piracy Off THE HORN OF AFRICA 21-22 (2009) (describing the various naval forces that have been conducting antipiracy operations off the Horn of Africa); David Gauvey Herbert, Piracy Is Down, and Moving Farther Out, BuRn AfTER READING (Apr. 21, 2010), http://burnafter reading.nationaljournal.com/2010/04/piracy-is-down-and-why-thats-b.php (suggesting that the EU, NATO, and U.S. antipiracy operations cost slightly less than US\$1.9 billion per year to support).

7. See, e.g., Special Adviser on Legal Issues Related to Piracy off the Coast of Somalia, Report of the Special Adviser to the Secretary-General on Legal Issues Related to Piracy off the Coast of Somalia, qף 14, 43, U.N. Doc. S/2011/30 (Jan. 24, 2011) (by Jack Lang) [hereinafter Lang Report]; U.N. Secretary-General, Report of the Secretary-General Pursuant to Security Council Resolution 1897 (2009), \36, U.N. Doc. S/2010/556 (Oct. 27, 2010); U.N. Secretary-General, Report of the Secretary-General on Possible Options To Further the Aim of Prosecuting and Imprisoning Persons Responsible for Acts of Piracy and Armed Robbery at Sea off the Coast of Somalia, Including, in Particular, Options for Creating Special Domestic Chambers Possibly with International Components, a Regional Tribunal or an International Tribunal and Corresponding Imprisonment Arrangements, Taking into Account the Work of the Contact Group on Piracy off the Coast of Somalia, the Existing Practice in Establishing International and Mixed Tribunals, and the Time and Resources Necessary To Achieve and Sustain Substantive Results, ๆ 9, U.N. Doc. S/2010/394 (July 26, 2010) [hereinafter $S / 2010 / 394$ Report].

8. Lang Report, supra note 7, $₫ 43$. 
can launch their attacks and yet face little threat of prosecution and punishment even if they are captured by the world's navies.

One reason cited for this culture of impunity is the purported lack of domestic legislation to facilitate the prosecution of suspected pirates. ${ }^{9} \quad$ For example, in April 2010, the United Nations Security Council recognized the lack of domestic legislation as one of the major obstacles to more broad-based and frequent piracy prosecutions, and it called on all states to rectify the present culture of impunity by encouraging states to criminalize piracy under their national laws and to consider favorably the prosecution of piracy suspects and the imprisonment of convicted pirates. ${ }^{10}$ In November 2010, the Security Council again noted that states lacked sufficient domestic legislation to prosecute pirates. ${ }^{11}$ In January 2011, the Special Adviser to the Secretary-General on Legal Issues Related to Piracy off the Coast of Somalia, Mr. Jack Lang, made a similar call to action, noting that the "[f]ailure to criminalize piracy in domestic law is the first obstacle to effective prosecution."

But, what exactly is lacking: legislation or the political will to prosecute pirates? After all, universal jurisdiction over piracy has existed for more than 100 years. ${ }^{13}$ In addition, most states are parties to the United Nations Convention on the Law of the Sea (UNCLOS) and the Convention for the Suppression of Unlawful Acts Against the Safety of Maritime Navigation (the SUA Convention), both of which authorize and encourage nations to cooperate in prosecuting acts of maritime piracy. ${ }^{14}$ Given this legal framework, should we not expect that states would have domestic laws criminalizing piracy and would

9. See id. $\uparrow 73$. In an earlier article, I explored another reason often cited to explain nations' relative unwillingness to prosecute piracy cases: namely, states' fears that pirates tried in their countries might later bring claims seeking asylum. See Yvonne M. Dutton, Pirates and Impunity: Is the Threat of Asylum Claims a Reason To Allow Pirates To Escape Justice?, 34 FORDHAM INT'L L.J. 236 (2011) (analyzing the texts of various international treaties that govern asylum and nonrefoulement, together with interpretations of the provisions in those treaties, and concluding that even if there is some small risk that some pirates can mount successful claims, developed nations should assume that risk so that pirates may be brought to justice and future acts of maritime piracy may be deterred).

10. See S.C. Res. 1918, U.N. Doc. S/RES/1918 (Apr. 27, 2010).

11. See S.C. Res. 1950, $\uparrow \uparrow$ 12-13, U.N. Doc. S/Res/1950 (Nov. 23, 2010).

12. Lang Report, supra note 7, 9 ๆ 46, 51, 73.

13. See, e.g., Edwin D. Dickinson, Is the Crime of Piracy Obsolete?, 38 HARV. L. REV. 334, 335-39 (1925) (suggesting the crime of piracy has been subject to universal jurisdiction since the seventeenth century); Máximo Langer, The Diplomacy of Universal Jurisdiction: The Political Branches and the Transnational Prosecution of International Crimes, 105 AM. J. INT'L L. 1, 3 \& n.4 (2011) (noting that states have claimed universal jurisdiction over the crime of piracy for more than 200 years).

14. See discussion infra Part II.B-C. 
use those laws to prosecute the pirates the states have gone to such lengths to capture? Or is the problem that states have criminalized piracy, but their legislation is insufficient to cover the kinds of acts that modern-day pirates are committing? On the other hand, if states have not implemented any domestic laws criminalizing piracy, can there be any reason for failing to do so other than a lack of political will to share the burden of prosecuting pirates?

This Article explores these questions by examining the status of domestic antipiracy laws in about fifty states for which information is available in English. ${ }^{15}$ Although the questions posed above cannot be answered with certainty, an analysis of the various state laws provides some interesting insights about the precise nature of state antipiracy laws and also about the likely reasons why states typically refuse to undertake piracy prosecutions.

First, the analysis shows that relatively few states provide for universal jurisdiction over piracy by fully incorporating the definition contained in UNCLOS or otherwise. In fact, many states do not even specifically criminalize piracy: they rely instead on more general categories of crime, such as robbery, assault, kidnapping, or murderall of which require a national or territorial nexus between the state and the crime committed in order for the state to exercise jurisdiction. Furthermore, many of those states that define the crime of piracy also require some nexus to the offense before they will exercise jurisdiction. The implication from this analysis supports a conclusion that on the whole, states lack the political will to share the burden of prosecuting pirates, even though most states are also parties to the treaties that encourage state cooperation to prosecute acts of maritime piracy.

15. Much of the information about state piracy laws used in this study was gathered in response to an International Maritime Organization (IMO) Circular Letter sent to states requesting details about their piracy laws. See Circular Letter No. 2933 from International Maritime Organization (IMO) to all IMO Member States (Dec. 23, 2008) [hereinafter IMO Circular Letter], available at http://www.imo.org/OurWork/Security/SecDocs/Documents/ Piracy/CL2933.pdf (requesting "samples of national legislation, if any, to prevent, combat and punish acts of piracy and armed robbery at sea, as well as any pertinent information on such national legislation"). The state responses to the IMO Circular Letter are collected on a Web site maintained by the United Nations Division for Ocean Affairs and the Law of the Sea (UNDOALOS), together with the IMO and the United Nations Office on Drugs and Crime (UNODC). As of October 26, 2011, when the Web site was last updated, it contained information about the piracy laws of fifty-eight states - only some of which reported in English. National Legislation on Piracy, U.N. Division for OCEAN AfF. \& THE LAW OF THE SEA, http://www.un.org/depts/los/piracy/piracy_national_legislation.htm (last updated Oct. 26, 2011). Independent research using a variety of resources revealed some additional state piracy laws available in English. 
Second, in addition to evidencing a lack of political will among states to prosecute piracy offenses using universal jurisdiction, the analysis also shows that the laws states have enacted may not be sufficient to allow for a successful prosecution of today's pirates. Obviously, the laws that require a nexus between the state and the offense can lead to a situation where a state's navy captures alleged pirates only then to let them go because the attack did not occur in the state's territory and the state's citizens are not the perpetrators or the victims of the attack. In fact, in November 2010, the Mombasa High Court of Kenya ordered the release of nine alleged pirates that were transferred to Kenya for trial by Germany's naval patrols on the grounds that Kenya's laws did not permit piracy prosecutions unless the state had some nexus to the offense. ${ }^{16}$ Although Kenya subsequently amended its laws and now incorporates the full UNCLOS definition of piracy, the court concluded that the state's previous piracy provisions did not allow Kenya to exercise jurisdiction over acts of piracy not occurring in its territorial waters and to which it had no other connection. The previous law-section 69 of the Penal Code - provided that "any person who, in territorial waters or upon the high seas, commits any act of piracy jure gentium is guilty of the offence of piracy." ${ }^{17}$ The court, however, decided that because section 5 of the Penal Code only allowed Kenya to exercise jurisdiction over acts occurring within Kenya and its territorial waters, it was "juridically paramount to" section 69, such that Kenya had no jurisdiction over offenses occurring on the high seas, notwithstanding section 69 s language. ${ }^{18}$

However, even when laws allow states to exercise universal jurisdiction over piracy, those laws may remain insufficient in some instances to ensure the successful prosecution of modern pirates. For example, some states' laws provide rather broadly that piracy is a crime as defined by the law of nations - a definition which arguably could more specifically outline the exact elements of the offense. Indeed, in United States $v$. Said, the United States District Court for the

16. Celestyne Achieng, Kenya Court Orders Release of Somali Piracy Suspects, REUTERS (Nov. 9. 2010), http://uk.reuters.com/article/2010/11/09/somalia-piracy-kenyaidUKLDE6A81SI20101109.

17. High Court Frees Suspected Pirates for Lack of Jurisdiction over High Seas, INT'L L. OFF. (Dec. 21, 2010), http://www.internationallawoffice.com/newsletters/detail. aspx?g=ba8d556e-f187-402b-a70d-f54abd170d20 (internal quotation marks omitted).

18. See Ex parte Mohamud Mohamed Hashi \& 8 Others (2010) K.L.R. (H.C.K.) (Kenya), available at http://kenyalaw.org/CaseSearch/view_preview1.php?link=438-8514778 571544330244. 
Eastern District of Virginia dismissed charges under 18 U.S.C. § 1651, a statute defining piracy by reference to the law of nations. The court found that the "law of nations" piracy definition required acts more akin to sea robbery and an actual taking of property, rather than simply acts preparatory to an attack. ${ }^{19}$ Because the defendants were captured before they had taken control of an American warship or obtained any property from it, the court decided that they had not committed piracy within the meaning of the statute..$^{20}$ Whether the decision was correct is the subject of some debate. ${ }^{21}$ However, the Said decision still illustrates some of the difficulties that can arise if states do not specifically define the elements of a piracy offense.

In sum, as these examples illustrate, states need to implement laws allowing for the exercise of universal jurisdiction over piracy offenses. States also need to ensure that the laws they implement are sufficient to hold pirates accountable for their crimes-including crimes that are not fully completed at the time of capture. This Article analyzes a variety of state antipiracy laws with the precise object of identifying areas where those laws may be improved so as to ensure that they are capable of adequately bringing pirates to justice.

Part II of this Article provides a brief overview of the international legal framework which allows, and indeed encourages, nations to prosecute acts of maritime piracy. Part III contains some background on the nature of modern piracy. It also explains some of the steps that the international community has taken to combat the piracy problem, while at the same time briefly describing more fully the culture of impunity that generally characterizes the international response to piracy. Part IV examines the domestic antipiracy laws that states have enacted - or the more general provisions states suggest may cover acts of piracy - and groups those laws into several categories according to their primary characteristics. As to those nations that have enacted laws criminalizing piracy, in Part V, I analyze the various types of laws and discuss areas of vulnerability. This Article concludes by suggesting that if they have not already done so,

19. 757 F. Supp. 2d 554 (E.D. Va. 2010).

20. Id.

21. The Said decision has been criticized by at least one commentator. See John Schwartz, Somalis No Longer Face Federal Piracy Charges, N.Y. TimeS, Aug. 18, 2010, at A16 (quoting Professor Eugene Kontorovich as stating that the court's decision was likely wrong). Furthermore, another judge in the Eastern District of Virginia reached a different conclusion about whether acts preparatory to an actual boarding and taking of property are required for an act to constitute piracy under the "law of nations." See United States v. Hasan, 747 F. Supp. 2d 599, 635 (E.D. Va. 2010). 
nations should pass comprehensive antipiracy laws that contain a framework for exercising universal jurisdiction over those who commit pirate attacks. States should also embrace their duty to share in the burden of protecting the international community and innocent seafarers from continued acts of piracy by prosecuting those who commit piracy. ${ }^{22}$ Although states may have many reasons to sit back and wait for others to prosecute maritime piracy offenses, pirates are unlikely to be deterred from their violent and criminal activities unless the world community - and wealthy, developed nations in particularshare the burden, expense, and difficulty of trying those pirates.

\section{THE INTERNATIONAL LEGAL FRAMEWORK GOVERNING THE CRIME OF PIRACY}

\section{A. Universal Jurisdiction}

While states ordinarily have no jurisdiction to prosecute crimes without some nexus to the prohibited act, piracy is the quintessential crime over which they may exercise universal jurisdiction. ${ }^{23}$ Under customary international law, ${ }^{24}$ states may prosecute acts of piracy even

22. In an earlier article, I argued that piracy should be included within the jurisdiction of the International Criminal Court. Yvonne M. Dutton, Bringing Pirates to Justice: A Case for Including Piracy Within the Jurisdiction of the International Criminal Court, $11 \mathrm{CHI}$. J. INT'L L. 197 (2010). However, prosecuting pirates in national courts is still necessary even if piracy is eventually included within the jurisdiction of the International Criminal Court. The International Criminal Court relies on a system of complementarity and expects that state parties will prosecute serious crimes of concern to the international community in their domestic courts. Including piracy within the jurisdiction of the International Criminal Court would nevertheless provide another avenue to prosecute captured pirates, particularly in those instances where only a state with weak judicial institutions otherwise has the best case for invoking jurisdiction over the offense. If piracy is not included within the International Criminal Court or some other international tribunal, it is even more imperative that developed states criminalize piracy and use those laws to prosecute pirates in their domestic courts. See id. at $239-40$.

23. See, e.g., M. Cherif Bassiouni, The History of Universal Jurisdiction and Its Place in International Law, in UNIVERSAL JURISDICTION: NATIONAL COURTS AND THE PROSECUTION of Serious Crimes Under InTERnAtional LaW 39, 47-48 (Stephen Macedo ed., 2004); Miriam Cohen, The Analogy Between Piracy and Human Trafficking: A Theoretical Framework for the Application of Universal Jurisdiction, 16 BuFF. HuM. RTS. L. REV. 201, 201 (2010) (noting that the doctrine of universal jurisdiction was originally developed to address piracy that occurred on the high seas, outside of any state's jurisdiction); Jon D. Peppetti, Building the Global Maritime Security Network: A Multinational Legal Structure To Combat Transnational Threats, 55 NAVAL L. REV. 73, 104 (2008).

24. "Customary international law results from a general and consistent practice of states followed by them from a sense of legal obligation." RESTATEMENT (THIRD) OF FOREIGN RELATIONS LAW § 102(2) (1986). According to the Restatement, "International agreements constitute practice of states and as such can contribute to the growth of customary [international] law." Id. $\S 102 \mathrm{cmt}$. i. Courts in the United States conclude that a principle 
where those acts occur outside their territory and involve none of their citizens as either perpetrators or victims. ${ }^{25}$ Universal jurisdiction exists to facilitate the shared interest of the world community in ensuring that certain serious crimes of an international character do not go unpunished. $^{26}$ In the case of piracy, universal jurisdiction is warranted because of the general heinousness of piratical acts and the fact that those acts are directed against ships and persons of any and all nations, disrupting international trade and commerce. ${ }^{27}$ Accordingly, states may exercise criminal jurisdiction over acts of maritime piracy "based solely on the nature of the crime, without regard to where the crime was committed, the nationality of the alleged or convicted perpetrator, the nationality of the victim, or any other connection to the state exercising such jurisdiction.",28

From a domestic perspective, however, for a state to exercise universal jurisdiction over acts of piracy, it will still need to authorize that exercise of jurisdiction - either by permitting its courts to draw directly from international law or by enacting legislation implementing international law. ${ }^{29} \quad$ Furthermore, for the exercise of universal

has become part of customary international law when (1) the principle is universally recognized by states, (2) states cede to it out of a sense of legal obligation through general and consistent practice, and (3) the "wrong" addressed by the principle is one of mutual concern to states. See, e.g., Flores v. S. Peru Copper Corp., 414 F.3d 233, 248-49 (2d Cir. 2003); Filartiga v. Pena-Irala, 630 F.2d 876, 888 (2d Cir. 1980).

25. See Anthony J. Colangelo, The Legal Limits of Universal Jurisdiction, 47 VA. J. INT'L L. 149, 151 (2006); see also 4 WiLliam BlaCKSTONE, COMMENTARIES *72; M. Cherif Bassiouni, Universal Jurisdiction for International Crimes: Historical Perspectives and Contemporary Practice, 42 VA. J. INT'L L. 81, 110-12 (2001).

26. See Bassiouni, supra note 23, at 42.

27. See, e.g., Jeffrey M. Blum \& Ralph G. Steinhardt, Federal Jurisdiction over International Human Rights Claims: The Alien Tort Claims Act After Filartiga v. Peña-Irala, 22 HARV. INT'L L.J. 53, 60 (1981) (stating that piracy is subject to universal jurisdiction because of its heinousness); Kenneth C. Randall, Universal Jurisdiction Under International Law, 66 TEX. L. REV. 785, 794-95 (1988) (suggesting that the most accurate rationale for providing universal jurisdiction over piracy relies on the wicked and heinous nature of piracy offenses, which involve violence and depredation, and the fact that piracy is directed against ships of all nations). The United States Supreme Court early recognized the pirate as an enemy of all mankind over which states could exercise universal jurisdiction because the pirate "commits hostilities upon the subjects and property of any or all nations, without any regard to right or duty, or any pretence of public authority." See United States v. Cargo of the Brig Malek Adhel, 43 U.S. (2 How.) 210, 232 (1844).

28. The Princeton Principles on Universal JuRisdiction 28 (Stephen Macedo ed., 2001).

29. Wolfgang Kaleck, From Pinochet to Rumsfeld: Universal Jurisdiction in Europe 1998-2008, 30 Mich. J. INT'L L. 927, 958 (2009); see also Colangelo, supra note 25, at 162 \& n.37 (explaining the monist approach to international law whereby states' constitutional systems recognize the supremacy of international law and the dualist approach whereby states must implement international law through domestic legislation). 
jurisdiction to be proper, the state's domestic legislation criminalizing piracy should not exceed the scope of the customary international law. ${ }^{30}$ In the case of maritime piracy, commentators appear to agree that the definition of piracy contained in UNCLOS reflects customary international law. ${ }^{31}$ Therefore, regardless of whether they are parties to UNCLOS, all states may promulgate domestic laws authorizing the exercise of universal jurisdiction over piratical acts consistent with the terms of that treaty. ${ }^{32}$

As discussed below, in addition to being able to exercise universal jurisdiction over piracy, states that are parties to UNCLOS and the SUA Convention also have jurisdiction over certain acts of piracy pursuant to the terms of those treaties. ${ }^{33}$ The great majority of states are parties to these two treaties: 162 are parties to UNCLOS, ${ }^{34}$ and 156 are parties to the SUA Convention. ${ }^{35}$

\section{B. UNCLOS's Piracy Provisions}

Article 105 of UNCLOS codifies piracy's status as a crime subject to universal jurisdiction, providing that any state may exercise its right to repress piracy by seizing pirate ships and arresting pirates. ${ }^{36}$ The acts over which states have universal jurisdiction pursuant to the terms of the treaty are defined in article 101:

30. See Colangelo, supra note 25, at 161-62 (explaining that a state's ability to invoke universal jurisdiction is limited by the international community's consensus on the definition of the substantive crime).

31. Peppetti, supra note 23, at 91-92 \& n.111; Tullio Treves, Piracy, Law of the Sea, and Use of Force: Developments Off the Coast of Somalia, 20 EUR. J. INT'L L. 399, 401 (2009).

32. See, e.g., Colangelo, supra note 25, at 186; Peppetti, supra note 23, at 97.

33. United Nations Convention on the Law of the Sea arts. 100-107, 110, Dec. 10, 1982, 1833 U.N.T.S. 397 [hereinafter UNCLOS]; Convention for the Suppression of Unlawful Acts Against the Safety of Maritime Navigation, Mar. 10, 1988, 1678 U.N.T.S. 222 [hereinafter SUA Convention].

34. For a list of state ratifications, see Chronological Lists of Ratifications of, Accessions and Successions to the Convention and Related Agreements as at 03 June 2011, U.N. DIVISION FOR OCEAN AFF. \& THE LAW OF THE SEA, http://www.un.org/depts/los/ reference_files/chronological_lists_of_ratifications.htm (last updated June 3, 2011). Although the United States is not a party to UNCLOS, it did ratify an earlier version of the treaty with identical provisions regarding piracy. See Convention on the High Seas, Apr. 29, 1958, 13 U.S.T. 2312, 450 U.N.T.S. 82 [hereinafter Geneva Convention]. Furthermore, as noted above, the provisions of UNCLOS relating to piracy are generally accepted as reflecting customary international law. See, e.g., R. Chuck Mason, Cong. Research Serv., R41455, Piracy: A Legal Definition (2010); Peppetti, supra note 23, at 91-92 \& n.111.

35. See Status of Conventions, INT'L MAR. ORG., http://www.imo.org/About/ Conventions/StatusOfConventions/Pages/Default.aspx (last visited Apr. 17, 2012).

36. See UNCLOS, supra note 33, art. 105. 
(a) any illegal acts of violence or detention, or any act of depredation, committed for private ends by the crew or the passengers of a private ship or a private aircraft, and directed:

(i) on the high seas, against another ship or aircraft, or against persons or property on board such ship or aircraft;

(ii) against a ship, aircraft, persons or property in a place outside the jurisdiction of any State;

(b) any act of voluntary participation in the operation of a ship or of an aircraft with knowledge of facts making it a pirate ship or aircraft;

(c) any act of inciting or of intentionally facilitating an act described in subparagraph (a) or (b). ${ }^{37}$

In addition, under article 103, a ship is a pirate ship "if it is intended by the persons in dominant control to be used for the purpose of committing one of the acts referred to in article 101.,"38

In short, under UNCLOS, piracy is essentially defined as (1) an illegal act of violence or detention, (2) committed for private ends, (3) on the high seas, and (4) directed against another ship. ${ }^{39}$ Nevertheless, the language describing these elements is necessarily subject to different interpretations, and in some cases, scholars disagree on precisely what acts might be covered under UNCLOS's definition of piracy. Below, I discuss each of these elements in greater detail.

First, in terms of the precise criminal acts covered by the treaty, UNCLOS appears to cover completed acts of piracy, as well as preparatory acts and attempts. Article 101(a) defines piracy as any illegal acts of violence or detention or acts of depredation against another ship, its passengers, or property. ${ }^{40}$ Article 101(b) appears to cover any attempts to commit those acts of violence, detention, or depredation. ${ }^{41}$ According to article 101(b), included within the definition of piracy is any voluntary participation in the operation of a

37. Id. art. 101 .

38. Id. art. 103.

39. UNCLOS's piracy provisions are identical to the piracy provisions in the Geneva Convention on the High Seas (articles 13-21) and have their origin in the Harvard Research Committee's project of the 1930s which undertook to codify the crime of piracy. See Douglas Guilfoyle, Shipping InTERdiction AND the Law OF the SeA 30 (2009). The Harvard Research Committee's piracy project resulted in The Harvard Research in International Law Draft Convention and Comment on Piracy, 26 AM. J. InT'L L. (Supp.) 739 (1932).

40. UNCLOS, supra note 33, art. 101(a). "Depredation" includes the acts of plundering and pillaging. BLACK's LAW DiCTIONARY 507 (9th ed. 2004).

41. See Kontorovich \& Art, supra note 2, at 442 \& n.29; UNCLOS, supra note 33, art. 101(b); see also Lang Report, supra note 7, ๆ 59 (stating that UNCLOS's definition of piracy includes the intention to commit acts of piracy per article 103). 
pirate ship, which article 103 defines as any ship intended by its leaders to be used to commit acts of piracy. ${ }^{42}$ In addition, article 101(c) defines as piracy inciting or facilitating acts of violence or detention against a ship. ${ }^{43}$

Second, for an act to constitute piracy under UNCLOS, the act must be committed for "private ends." suggested this language limits UNCLOS's reach, such that politically motivated acts of terrorism against ships and their crew members on the high seas would not be deemed acts of piracy. ${ }^{45}$ In other words, UNCLOS covers only those acts that are commercially motivated and carried out for private gain rather than for a cause. ${ }^{46}$ Other commentators, however, argue that the "private ends" language is not so limiting. ${ }^{47}$ Rather, they suggest the language was likely meant to exclude from UNCLOS's coverage only those unrecognized insurgents who act solely against a foreign government and ships acting pursuant to public authority. ${ }^{48}$ Although the commentators proffering the less limiting interpretation of the language claim to have the better argument and one supported by an analysis of relevant documentary history, the fact remains that neither UNCLOS nor any of the

42. UNCLOS, supra note 33, arts. 101(b), 103.

43. Id. art. 101(c).

44. Id. art. 101(a). UNCLOS's predecessor, the Geneva Convention on the High Seas, similarly defines piracy as "[a]ny illegal acts of violence, detention or any act of depredation, committed for private ends by the crew or the passengers of a private ship ... [o]n the high seas, against another ship ... or against persons or property on board such ship." Geneva Convention, supra note 34, art. 15.

45. See, e.g., Lawrence Azubuike, International Law Regime Against Piracy, 15 AnN. SuRV. INT'L \& COMP. L. 43, 52-53 (2009); Zou Keyuan, Implementing the United Nations Convention on the Law of the Sea in East Asia: Issues and Trends, 9 Sing. Y.B. INT'L L. 37, 44 (2005); Tammy M. Sittnick, State Responsibility and Maritime Terrorism in the Strait of Malacca: Persuading Indonesia and Malaysia To Take Additional Steps To Secure the Strait, 14 PAC. Rim L. \& Pol'y J. 743, 758 (2005); Erik Barrios, Note, Casting a Wider Net: Addressing the Maritime Piracy Problem in Southeast Asia, 28 B.C. InT'L \& COMP. L. REv. 149, 156 (2005).

46. Joseph M. Isanga, Countering Persistent Contemporary Sea Piracy: Expanding Jurisdictional Regimes, 59 AM. U. L. REV. 1267, 1283-84 (2010).

47. See, e.g., Michael Bahar, Attaining Optimal Deterrence at Sea: A Legal and Strategic Theory for Naval Anti-Piracy Operations, 40 VAND. J. TRANSNAT'L L. 1, 27-37 (2007).

48. Id. Professor Douglas Guilfoyle makes a similar point, arguing that the "private ends" language must be interpreted broadly and was not meant to exclude politically motivated acts from the definition of piracy. He suggests, "The test of piracy lies not in the pirate's subjective motivation, but in the lack of public sanction for his or her acts." GuILFOYLE, supra note 39, at 31-37. Professor Guilfoyle supports his conclusion about the meaning of the "private ends" exclusion by reference to the relevant preparatory documents supporting the adoption of the piracy provisions in the Harvard Research Draft and the Geneva Convention. See id. at 32. 
codifications of piracy on which its provisions were allegedly based define the term "private ends." Accordingly, some captured pirates could seize on the "private ends" language as an opportunity to claim their acts were politically motivated. Should the evidence support that claim, at least some courts could conclude that the UNCLOS definition of piracy was not satisfied.

Third, UNCLOS's definition of piracy includes only those acts that occur on the high seas or outside the territory of any state. ${ }^{50} \mathrm{~A}$ state's territorial waters may extend twelve miles from its coastline, and only that state has jurisdiction to prosecute wrongful acts occurring in its sovereign territory. ${ }^{51}$ Furthermore, although article 58 of UNCLOS preserves universal jurisdiction over piracy within the exclusive economic zones (EEZ) of states - which by virtue of article 57 can extend some 200 miles from the coastline - states seeking to apprehend pirates in such areas must not interfere with the rights of the state claiming that EEZ. ${ }^{52}$ For this reason, some commentators have suggested that exercising universal jurisdiction over piracy in the EEZs may be problematic, even though authorized by UNCLOS. ${ }^{53}$

49. Professor Malvina Halberstam notes that neither the Harvard Research Draft nor the Geneva Convention defines "private ends." Malvina Halberstam, Terrorism on the High Seas: The Achille Lauro, Piracy and the IMO Convention on Maritime Safety, 82 AM. J. INT'L L. 269, 277 (1988). She does state that her review of the relevant preparatory documents to the Harvard Research Draft and the Geneva Convention arguably supports the view that the "private ends" language was meant "to exclude acts by unrecognized insurgents who limited their attacks to the state from which they were seeking independence" and statesponsored ships. See id. However, Professor Halberstam also notes that UNCLOS does not define "private ends," and that she is unaware of any other recorded preparatory discussions indicating that the UNCLOS "private ends" provision was not meant to exclude all politically motivated acts. Id. at 284.

50. UNCLOS, supra note 33, art. 101.

51. Id. arts. 2-3. In addition, island states like Indonesia and the Philippines may claim within their territory all waters between the outermost points of their outermost islands. See id. arts. 46-54. Of course, the difficulty with limiting jurisdiction to the territorial state is that the state may be unwilling or unable - for political, financial, or other reasons - to prosecute acts of piracy or sea robbery occurring in its sovereign waters. See, e.g., MuNICH Re Group, Piracy - Threat at SEA: A Risk AnALysis 29 (2006) (suggesting that many nations with territorial jurisdiction over acts of piracy do not have the security, enforcement, and financial resources to catch and prosecute pirates).

52. See Samuel Pyeatt Menefee, The New "Jamaica Discipline": Problems with Piracy, Maritime Terrorism and the 1982 Convention on the Law of the Sea, 6 CONN. J. INT'L L. 127, 146-47 (1990) (citing Thomas A. Clingan, Jr., The Law of Piracy, in PIRACY AT SEA 168, 168-70 (Eric Ellen ed., 1989)); see also UNCLOS, supra note 33, arts. 57-58.

53. See Menefee, supra note 52, at 146-47; see, e.g., GuILFOYLE, supra note 39, at 45; see also J. Ashley Roach, Agora: Piracy Prosecutions; Countering Piracy off Somalia: International Law and International Institutions, 104 AM. J. INT'L L. 397, 398 (2010) (stating that it is well-settled that UNCLOS authorizes the exercise of universal jurisdiction over piracy in the EEZ); Martin Murphy, Piracy and UNCLOS: Does International Law Help 
Accordingly, although UNCLOS provides universal jurisdiction over acts of piracy occurring in international waters, it cannot be used to prosecute acts occurring in territorial waters. Fortunately, this means that the many attacks that Somali pirates have staged far out at sea are covered by UNCLOS's provisions. ${ }^{54}$ On the other hand, the numerous attacks in territorial waters and ports are not within UNCLOS's jurisdictional scope. $^{55}$

Fourth, some language in UNCLOS suggests that for an act to be deemed piracy, two ships must be involved. Article 101(a)(i) defines acts of piracy to include those illegal acts committed by the crew or passengers of a ship "against another ship.", Although article 101(a)(ii) does not include this same wording to define an act of piracy, commentators differ on whether piracy under UNCLOS includes internal seizures, violence by the crew, or passengers of one ship against that same ship. ${ }^{57}$ Thus, in some situations where two ships are not involved, the acts may not constitute piracy under UNCLOS.

Regional States Combat Piracy?, in Violence at SeA: Piracy in the Age of Global TERRORISM 155, 162 (Peter Lehr ed., 2007) (same).

54. See, e.g., PlOCH ET AL., supra note 6 (noting that some pirate attacks during 2009 occurred some 1000 nautical miles off the Somali coast). Furthermore, according to the IMB 2010 Annual Report, as a percentage of global incidents, piracy on the high seas has increased significantly over armed robberies in territorial waters. ICC-IMB 2010 REPORT, supra note 1, at 23. In addition, Professor Guilfoyle points out that when one excludes attacks in port, approximately fifty percent of reported incidents occur in international waters. See GuILFOYLE, supra note 39, at 51.

55. See, e.g., Robert C. Beckman, Combatting Piracy and Armed Robbery Against Ships in Southeast Asia: The Way Forward, 33 OCEAN DEV. \& INT'L L. 317, 328 (2002) (stating that none of the attacks in the Straits of Malacca and Singapore constituted piracy under UNCLOS because they took place in territorial waters); ICC-IMB 2010 REPORT, supra note 1 , at 29 (showing sixteen locations where ships were attacked at ports and anchorages three or more times during 2010).

56. UNCLOS, supra note 33, art. 101(a)(i) (emphasis added).

57. See Azubuike, supra note 45, at 53 (suggesting that piracy under UNCLOS requires two ships because the primary concern of international law in the high seas "is to protect outsiders and not necessarily the passengers of a given ship" because the domestic laws of the flag state can protect passengers); Bahar, supra note 47, at 38-39 (stating that the "two ship" language was meant only to exempt from the definition of piracy acts by one passenger or crew member against another); Eugene Kontorovich, International Decisions, United States v. Shi, 103 AM. J. INT'L L. 734, 737 (2009) (stating that treaty language and the preparatory papers support a conclusion that the two ship requirement is meant to screen out mutiny or other internal disturbances by crew and passengers, whose acts would remain within the jurisdiction of the flag state to prosecute); Menefee, supra note 52, at 144 (noting the controversy amongst scholars). 


\section{The SUA Convention's Piracy Provisions}

The SUA Convention, which was drafted in response to the Achille Lauro incident where Palestinian terrorists hijacked an Italian cruise liner, addresses some additional acts of maritime violence not covered by UNCLOS. ${ }^{58}$ First, the SUA Convention prohibits both completed attacks on ships and attempts to do the same, and it does not contain the limiting "private ends" or "two ships" language from UNCLOS. ${ }^{59}$ Pursuant to article 3, a prohibited offense is committed by anyone who unlawfully and intentionally (1) "seizes or exercises control over a ship by force or threat thereof or any other form of intimidation,", (2) "performs an act of violence against a person on board a ship if that act is likely to endanger the safe navigation of that ship, ${ }^{961}$ or (3) attempts to do any of the above. ${ }^{62}$ Indeed, the SUA Convention was enacted in part so that politically motivated attacks on ships could be prosecuted by the international community. ${ }^{63}$

In addition, the SUA Convention extends the definition of piracy to include attacks within territorial or archipelagic waters or in port ${ }^{64}$ if the ship is scheduled for international navigation. ${ }^{65}$ Unlike UNCLOS, however, the SUA Convention does not allow for the exercise of universal jurisdiction over acts of piracy. ${ }^{66}$ Only signatory states may prosecute violations of the SUA Convention and they need some nexus to the offense in order to do so. Specifically, a state may prosecute offenses under the SUA Convention provided that (1) the offense was against a ship flying its flag, (2) the offense occurred in its territory,

58. See, e.g., European Security and Defence Assembly [ESDA], Assembly of Western European Union, Report: The Role of the European Union in Combating Piracy, at 5-6, 15, ESDA Doc. No. A/2037 (June 4, 2009) [hereinafter Report: The Role of the European Union in Combating Piracy]; Halberstam, supra note 49, at 270-72; Isanga, supra note 46 , at 1292.

59. See SUA Convention, supra note 33, art. 3.

60. Id. art. 3(1)(1).

61. Id. art. $3(1)(2)$

62. Id. art. 3(2)(1)-(2).

63. See sources cited supra note 58

64. The SUA Convention applies "if the ship is navigating of [sic] is scheduled to navigate into, through or from waters beyond the outer limit of the territorial sea of a single State, or the lateral limits of its territorial sea with adjacent States." SUA Convention, supra note 33 , art. 4.

65. Id. arts. 4, 6. However, while the SUA Convention does theoretically cover acts of violence against persons on a ship while in port, as noted above, pursuant to article 3, those acts must also be "likely to endanger the safe navigation of [the] ship." Id. art. 3(2)(3). Because of this language, using the SUA Convention to prosecute attacks while a ship is docked may be difficult.

66. See, e.g., Isanga, supra note 46, at 1292; Kontorovich, supra note 57, at 738. 
(3) the offense was committed by a national of the state, or (4) a national of the state was a victim of the offense. ${ }^{67}$ Therefore, if a signatory state with the required nexus to the offense does not prosecute, or if the states with a nexus to the offense are not signatories to the SUA Convention, pirates and maritime terrorists will go unpunished notwithstanding the SUA Convention's increased territorial jurisdictional realm. ${ }^{68}$

\section{The PIRACy ThreAt AND the Response OF the INTERNATIONAL COMMUNITY}

\section{A. The Maritime Piracy Problem}

Maritime piracy is a real and modern problem - one that is only getting worse. In fact, pirate attacks were so frequent that by 2009 , one actual or attempted attack was reported every twenty-nine hours. ${ }^{69}$ Furthermore, there is no evidence to suggest that this troubling trend is changing its course. The number of attacks reported in the first quarter of 2011 was the highest ever recorded in the first quarter of any year since 1991 when the IMB started keeping records on worldwide piracy activity. ${ }^{70}$ In addition, Somali pirates are now able to stage attacks so far from shore that naval patrols have difficulty intercepting them. Pirates can operate up to 1000 nautical miles out to sea using "mother ships" from which they can launch high-speed maneuverable skiffs powered with large outboard motors. ${ }^{71}$ Many merchant vessels are no

67. SUA Convention, supra note 33, art. 6.

68. See George D. Gabel, Jr., Smoother Seas Ahead: The Draft Guidelines as an International Solution to Modern-Day Piracy, 81 TuL. L. REV. 1433, 1445 (2007) (citing Tina Garmon, Comment, International Law of the Sea: Reconciling the Law of Piracy and Terrorism in the Wake of September 11th, 27 TUL. MAR. L.J. 257, 273 (2002)).

69. Peter Chalk, Piracy Off the Horn of Africa: Scope, Dimensions, Causes and Responses, BROWn J. World AFF., Spring/Summer 2010, at 89, 90.

70. See InT'L Chamber of Commerce InT'L Mar. Bureau, Piracy AND ARMed Robbery Against Ships, Report For the Period of 1 January- 31 March 2011, at 23 (2011), available at http:/www.iccdanmark.dk/dox/News/April/2011\%20q1\%20imb\%20piracy\% 20report.pdf (reporting that in the first quarter of 2011 alone, pirates attacked 142 seafaring vessels).

71. See, e.g., PlOCH ET AL., supra note 6, at 8-9 (explaining the use of mother ships to facilitate attacking ships farther out to sea); Chalk, supra note 69, at 90-91 (reporting that pirate attacks occur as far as 500 to 1000 nautical miles from the Somali coast); Thaine Lennox-Gentle, Piracy, Sea Robbery, and Terrorism: Enforcing Laws To Deter Ransom Payments and Hijacking, 37 TRANSP. L.J. 199, 208 (2010) (discussing the attack on the Navy guided-missile frigate, the USS NICHOLAS, which occurred approximately 1000 nautical miles off the coast of Somalia near the Seychelles); Worldwide Hijackings Fall but Pirates Expand Area of Operation, DAILY NewS SRI LANKA (May 6, 2010), http://www.dailynews. $\mathrm{lk} / 2010 / 05 / 06 /$ bus60.asp (stating that pirate attacks had occurred some 1000 nautical miles off the Somali coast). 
match for the pirates: first, because the merchant vessels are relatively slow-moving, and second, because those vessels are often manned with small crews and carry no weapons (because the weapons would likely be impounded ashore by customs officers until the ship leaves

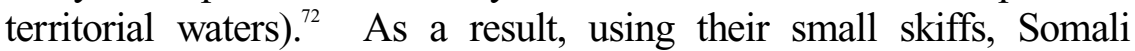
pirates - now typically armed with AK-47 rifles and rocket propelled grenade launchers - have successfully mounted attacks on supertankers such as the Saudi MV SIRIUS STAR (three times the size of an aircraft carrier) and the Greek MV MAURAN CENTAURUS (with a dead weight of 300,000 tons). ${ }^{73}$

Moreover, although the greatest number of pirate attacks in 2010 occurred off the coast of Somalia, modern maritime piracy significantly and negatively affects the international community as a whole. For example, pirates also mounted numerous attacks in Indonesia, Malaysia, the South China Sea, Vietnam, Bangladesh, Nigeria, and Peru. ${ }^{74}$ The victims of the attacks include flag states, ship owners, crew members, and cargo from all over the world. The IMB reports that in 2010 alone, pirates attacked ships of some 62 different states. $^{75} \quad$ As of December 31, 2010, Somali pirates reportedly were holding hostage $638 \mathrm{crew}$ members of different nationalities from 28 different ships. ${ }^{76}$

However, piracy does not harm only the direct victims of the attacks. It also threatens the free flow of commerce and the environment. About eighty percent of world trade flows through international sea lanes. ${ }^{77}$ When pirates hijack any of those ships, they interrupt global trade. When they hijack ships carrying supplies like oil, they threaten world energy supplies. Pirates did just that when they hijacked the Saudi oil tanker, the MV SIRIUS STAR, which was released in 2009 for a ransom of approximately US\$3 million. ${ }^{78}$ They

72. Ploch ET AL., supra note 6, at 10; Report: The Role of the European Union in Combating Piracy, supra note 58, at 5-6, 15.

73. Chalk, supra note 69, at 92-93; see also PLOCH ET AL., supra note 6, at 7.

74. ICC-IMB 2010 REPORT, supra note 1, at 5-6.

75. Id. at $15-16$.

76. Id. at 19. Between the end of December 2008 and early 2011, pirates held approximately 1900 people in 105 vessels hostage off the coast of Somalia. See Lang Report, supra note 7, $\ 29$.

77. See Michael Richardson, A Time Bomb for Global Trade: Maritime-Related Terrorism in an Age of Weapons of Mass Destruction, VIEWPOINTS: InST. S.E. ASIAN STUD. 31 (Feb. 24, 2004), http://cat.middlebury.edu/ scs/docs/Richardson, \%20Time\%20Bomb\%20 for\%20Global\%20Trade-ISEAS.pdf; see also Report: The Role of the European Union in Combating Piracy, supra note 58, at 4.

78. See PlOCH ET AL., supra note 6, at 9. 
did so again on February 9, 2011, when they seized the IRENE SL, a tanker carrying two million barrels of Kuwaiti oil to the United States. $^{79}$ In addition, piracy threatens the delivery of humanitarian assistance to the Horn of Africa ${ }^{80}$ Because many of the ships that flow through narrow sea lanes are carrying oil or other energy supplies, piracy also creates the risk of a major international environmental disaster. $^{81} \quad$ In short, "[p]iracy has reemerged as a global security threat. ${ }^{92}$

Finally, although some pirates may be "simple fisherman," maritime piracy has "become an organized, lucrative and attractive criminal activity undertaken for heinous ends." ${ }^{\text {"83 }}$ Recent reports indicate that attacks are being carried out by well-organized pirate gangs often headed by kingpins or backed by investors and/or corrupt officials lured by the hefty ransoms that pirates can now demand for the safe release of ships and their crews. ${ }^{84}$ In fact, Somalia boasts a

79. John Stewart, Somali Pirates: Steep Rise in Attacks, News-Insurances (Mar. 28, 2011), http://www.newsinsurances.co.uk/somali-pirates-steep-rise-in-attacks/0169475872.

80. See PlOCH ET AL., supra note 6, at 12. For example, about ninety-five percent of the humanitarian aid provided by the World Food Programme is transported by sea. See U.N. Secretary-General, Report of the Secretary-General Pursuant to Security Council Resolution 1846 (2008), 『 35, U.N. Doc. S/2009/146 (Mar. 16, 2009) [hereinafter Report Pursuant to Security Council Resolution 1846].

81. Peter Chalk, The Maritime Dimension of InTERnational Security: Terrorism, Piracy, AND Challenges fOr the United States 17 (2008), available at http://www.rand.org/pubs/monographs/2008/RAND_MG697.pdf; see also Lang Report, supra note $7, \llbracket 26$.

82. PlOCH ET AL., supra note 6, at 2. Assistant Secretary of State for PoliticalMilitary Affairs, Andrew Shapiro, made a similar point in his remarks at the International Institute for Strategic Studies, stating that "piracy off the Horn of Africa threatens not just specific ships, but has broader strategic implications." See MacKenzie C. Babb, U.S. Combats Growing Global Problem of Maritime Piracy, All AfricA (Mar. 31, 2011), http://www.allafrica.com/stories/201104190291.html.

83. $\quad$ Lang Report, supra note 7, 913.

84. See, e.g., Chalk, supra note 69, at 91-92 (stating that pirates in Somalia are organized along clan lines into a gang that reports to a leader who finances the attacks and thereafter takes the largest portion of the ransoms); James Kraska, Coalition Strategy and the Pirates of the Gulf of Aden and the Red Sea, 28 COMP. StrATEGY 197, 199 (2009) (stating that organized crime kingpins who live in Puntland or Mombasa, Kenya, are the recipients of most of the ransom monies collected by Somali pirates); David Ariosto, Sixth and Seventh Somalis Enter Guilty Pleas in Piracy Trial, CNN (May 24, 2011), http://articles.cnn.com/ 2011-05-24/us/virginia.somalia.pirate.plea_1_hijacking-piracy-pirates?_s=PM:US (reporting that according to court documents, the financier of an attack on a U.S.-flagged vessel was expected to receive thirty-five percent of any ransom received); Baldauf, supra note 4 (reporting that modern pirates are backed by a network of investors and corrupt officials who purchase equipment for them, assist in choosing targets based on the Lloyd's of London list of insured ships, and thereafter pay themselves by underground money transfers); Nick Wadhams, Somali Pirates Take the Money and Run, to Kenya, NPR (May 5, 2010), 
"stock exchange" where locals can contribute money or weapons to pirate gangs in exchange for a share of any ransoms. ${ }^{85}$ One wealthy former pirate told a reporter that the exchange hosted some seventytwo "maritime companies," ten of which had mounted successful hijackings in only a four-month period. ${ }^{86}$ Also, the ransom payments pirates demand for the safe return of their captives have increased so significantly over the last few years that they now average several millions of dollars - with individual pirates taking home tens of thousands of dollars as a reward for their participation. ${ }^{87}$ For example, at the age of nineteen, and having assisted in two ship hijackings, one Somali pirate had already made US $\$ 75,000 .^{88}$ Maritime piracy is such a lucrative business that the revenues from Somali piracy well exceed the entire budget of the government of Puntland (the area along the Somali coastline where piracy is most active). ${ }^{89}$ Piracy proceeds for 2009 are estimated at US\$82 million, whereas the annual revenues for the Puntland region for that same time period totaled only about US\$16 million. ${ }^{90}$

\section{B. Coordinated Antipiracy Naval Operations and the Security Council Resolutions Authorizing and Encouraging Antipiracy Operations}

The international community has shown its concern about the increasing frequency of piracy attacks and is engaged in naval operations designed to repress acts of maritime piracy. For example, beginning in 2007, some countries started providing naval escorts to the World Food Programme ships delivering humanitarian aid." In

http:/www.npr.org/templates/story/story.php?storyId=126510891 (reporting that piracy operations are often run by warlords and financiers from around the world).

85. Gienger, supra note 4; see also Mohamed Ahmed, Pirate Stock Exchange Helps Fund Hijackings, FIN. POST (Dec. 1, 2009), http://web.archive.org/web/20100204194104/ http://www.financialpost.com/news-sectors/story.html?id=2289558; Mohamed Ahmed \& Abdi Guled, Ransom Paid for Oil Tanker, Somalia Pirates Feud, ReuTERs (Jan. 17, 2010), http://www.reuters.com/article/2010/01/17/us-somalia-piracy-idUSTRE60G1J420100117.

86. See Ahmed, supra note 85.

87. See Gienger, supra note 4 (stating that ransom payments rose from an average of about US\$150,000 in 2005 to an average of about US\$5.4 million in 2010).

88. A Pirate's Life Is Good in Somalia, supra note 5.

89. See PlOCH ET AL., supra note 6, at 5-6 (discussing Puntland piracy); Lang Report, supra note 7, $\mid 23$ (comparing the proceeds of piracy to those of the annual revenues of the Puntland region).

90. Lang Report, supra note 7, $₫ 23$.

91. See, e.g., Report: The Role of the European Union in Combating Piracy, supra note 58, at 8; Roger Middleton, Piracy in Somalia: Threatening Global Trade, FEEDING LOCAL WARS 7 (2008), available at http://www.chathamhouse.org/files/12203_1008 
addition, in a general effort to ward off piracy attacks on sea traffic, in late 2008, a multinational naval force, CTF-150, started conducting counterpiracy operations around the Gulf of Aden, the Arabian Sea, and the Indian Ocean. ${ }^{92}$ In January 2009, CTF-150 was replaced by CTF-151, which is also a multinational naval force that combines military force, intelligence sharing, and coordinated patrols with the stated mission of conducting antipiracy operations in the Gulf of Aden and the waters off the coast of Somalia. ${ }^{93}$ The countries participating in CTF-151 have varied over time, but the list has included about two dozen ships from the United States, the United Kingdom, Canada, Denmark, France, Germany, Greece, Italy, the Netherlands, Pakistan, Saudi Arabia, Spain, South Korea, Turkey, and Yemen. ${ }^{94}$

The task force is complemented by other coordinated naval patrols. In 2008, the European Union launched a combined naval force, Operation ATALANTA, with the stated goals of protecting the safe travel of vessels and deterring, preventing, and repressing acts of piracy and armed robbery in the seas off the coast of Somalia. ${ }^{95}$ NATO has also sent ships to the Horn of Africa - first to protect World Food Programme vessels, and since August 2009, to conduct more general operations designed to deter and respond to acts of piracy. ${ }^{96}$ Other countries, including Russia, China, and India, have also sent naval forces to the region to provide escorts to ships and to engage in antipiracy operations. ${ }^{97}$

Since 2008, the United Nations Security Council has backed these coordinated naval efforts to counter piracy with a number of resolutions authorizing military action against Somali pirates at sea and within Somalia. ${ }^{98}$ In Resolution 1816, adopted on June 2, 2008, the Security Council authorized coalition navies cooperating with the Transitional Federal Government (TFG) for Somalia to enter the

piracysomalia.pdf. In March 2010, China offered to deploy naval forces to assist European Union forces that were escorting World Food Programme ships. See PlOCH ET AL., supra note 6 , at 16 .

92. See Report Pursuant to Security Council Resolution 1846, supra note 80, ๆ 30; see also PLOCH ET AL., supra note 6, at 16.

93. PlOCH ET AL., supra note 6, at 16.

94. Id.

95. See Council Decision 2008/918/CFSP, 2008 O.J. (L 330) 19 (EU); see also Chalk, supra note 69 , at 98 .

96. See, e.g., Ploch ET AL., supra note 6, at 17; Chalk, supra note 69, at 98.

97. See PlOCH ET AL., supra note 6, at 16.

98. See S.C. Res. 1851, U.N. Doc. S/RES/1851 (Dec. 16, 2008); S.C. Res. 1844, U.N. Doc. S/RES/1844 (Nov. 20, 2008); S.C. Res. 1838, U.N. Doc. S/RES/1838 (Oct. 7, 2008); S.C. Res. 1816, U.N. Doc. S/RES/1816 (June 2, 2008). 
territorial waters of Somalia and use "all necessary means to repress acts of piracy and armed robbery" for an initial period of six months. ${ }^{99}$ That authorization was extended for one year under Security Council Resolution 1846, dated December 2, 2008. ${ }^{100}$ By Resolution 1851, on December 16, 2008, the Security Council authorized even broader military action to combat piracy, allowing states to use land-based operations in Somalia to fight piracy. ${ }^{101}$ On November 30, 2009, the Security Council further extended the scope of allowable antipiracy operations in Somalia's territorial waters for another twelve months. ${ }^{102}$

These various resolutions authorizing and encouraging antipiracy operations have received overwhelming support from United Nations Member States, many of which stress the negative consequences they and the world community suffer as a result of the recent increase in pirate attacks. ${ }^{103}$ For example, in supporting Resolution 1851, the representative from Russia mentioned that its citizens had suffered from the ill effects of piracy, and that as a maritime power, safe shipping was of primary importance. ${ }^{104}$ The Chinese representative emphasized the fact that a number of vessels registered in or rented by China were hijacked in the waters off the coast of Somalia. ${ }^{105}$ The Japanese representative noted that as a maritime state and trading nation, Japan attaches great importance to ensuring the safety of marine navigation and security at sea through antipiracy measures because the matters are directly linked to the survival and prosperity of the country. ${ }^{106}$ The representative of India stated that the attacks not only impact shipping to and from Indian ports and their extended

99. See S.C. Res. 1816, supra note 98.

100. See S.C. Res. 1846, U.N. Doc. S/RES/1846 (Dec. 2, 2008).

101. See S.C. Res. 1851, supra note 98.

102. See S.C. Res. 1897, \7, U.N. Doc. S/RES/1897 (Nov. 30, 2009).

103. For example, states unanimously supported Resolution 1851 authorizing states to conduct land-based operations in Somalia to fight piracy. S.C. Res. 1851, supra note 98, 912. Based on Resolution 1851, states formed the Contact Group on Piracy off the Coast of Somalia (Contact Group). As of June 2011, sixty nations were members of the group, which has working groups to focus on a number of counterpiracy efforts. See Contact Group on Piracy off the Coast of Somalia Meets in New York, U.S. DeP'T StATE (Mar. 21, 2011), http://www.state.gov/r/pa/prs/ps/2011/03/158712.htm. The working groups are focused on (1) military coordination and information sharing, (2) judicial aspects of piracy, (3) shipping self-awareness, and (4) improvement of diplomatic and public information aspects of piracy. See Contact Group on Piracy off the Coast of Somalia Marks First Anniversary, U.S. DeP'T STATE (Jan. 26, 2010), http://www.state.gov/r/pa/prs/ps/2010/01/135862.htm.

104. United Nations Security Council 6046th Meeting, Dec. 16, 2008, The Situation in Somalia, U.N. Doc. S/PV.6046, at 3 (statement of Mr. Lavrov, Representative of the Russian Federation).

105. Id. at 5 (statement of Mr. He Yafei, Representative of China).

106. Id. at 24 (statement of Mr. Nishimura, Representative of Japan). 
neighborhood, but that they also exact a heavy impact upon India because the international merchant marine has a substantial proportion of persons of Indian origin. ${ }^{107}$ Norway's representative emphasized the threat to his country from piracy, inasmuch as about 1000 Norwegian ships pass through the Gulf of Aden each year. ${ }^{108}$ The representative from Turkey pointed out that two Turkish commercial vessels had already been attacked and were still being held hostage. ${ }^{109}$

In sum, the international community seems concerned about maritime piracy and is expending time, energy, and resources in an effort to prevent and combat it. Indeed, the world community seems so concerned about the dangers posed by maritime piracy that it is spending more than US\$1 billion annually to support the multinational naval forces that are patrolling pirate-infested waters in an effort to deter pirate activity. ${ }^{110}$

\section{Nations'Reluctance To Prosecute Captured Pirates and the General Culture of Impunity}

The naval patrols must be credited with repressing piracy to some extent. Naval forces apparently "thwarted 126 attacks in 2008, 176 in 2009 and 127 in 2010." ${ }^{111}$ Furthermore, the navies have been successful in capturing many pirates who have attacked vessels at sea. Reports indicate that between January and August 2009 alone, naval patrols captured 517 pirates and killed $10 .{ }^{112}$

However, as noted above, maritime piracy is only becoming more common and more lucrative. ${ }^{113}$ As the Lang Report explains, the number of attacks in absolute terms has continued to grow despite the presence of the various naval patrols and the various Security Council resolutions. ${ }^{114}$ Many have pointed to the prevalence of the navies' "catch and release" policies to help explain the increased frequency of piracy. ${ }^{115}$ Indeed, although as of December 31, 2010, some 738 pirates

107. Id. at 32 (statement of Mr. Sen, Representative of India).

108. Id. at 25 (statement of Mr. Wetland, Representative of Norway).

109. Id. at 26 (statement of Mr. Ilkin, Representative of Turkey).

110. See sources cited supra note 6.

111. Lang Report, supra note 7, $₫ 39$.

112. See Ploch ET AL., supra note 6, at 22.

113. See supra notes 1-5 and accompanying text.

114. Lang Report, supra note 7, \39; see Raymond Gilpin, Counting the Costs of Somali Piracy 3 (U.S. Inst. of Peace, Working Paper, 2009), available at http://www. usip.org/files/resources/1_0.pdf (noting that in the first half of 2009, pirate attacks were on the rise notwithstanding the deployment of a multinational armada in 2008).

115. See S/2010/394 Report, supra note 7, I9 ("In order to be effective, naval operations apprehending suspects should result in prosecutions. The risk otherwise is that 
were being held for prosecution, this is only a tiny fraction of the number of individuals who have been captured for allegedly planning or participating in maritime piracy attacks because approximately nine out of ten suspected pirates are released without prosecution. ${ }^{116}$ Equally discouraging is the fact that some of the pirates who were previously apprehended and released have thereafter been identified as repeat offenders. ${ }^{117}$ Thus, while the naval fleets should certainly be commended for thwarting attacks and apprehending pirates, absent a significant increase in criminal prosecutions, pirates are unlikely to be deterred from committing their violent and lucrative acts. ${ }^{118}$

Of course, some pirates are being prosecuted. However, they are most frequently tried by Kenya or other African states - rather than by the states of the capturing navies. ${ }^{119}$ Of the 738 suspected pirates being held for prosecution as of December 2010, about $90 \%$ will be tried in Somalia, Kenya, Yemen, the Seychelles, the Maldives, Oman, and Tanzania. ${ }^{120}$ In fact, during 2008 and 2009 alone, the United States, the United Kingdom, Germany, France, Spain, Italy, and Sweden transferred 107 suspected pirates to Kenya to be prosecuted. ${ }^{121}$ During

suspects are released at sea, or repatriated, and return to commit further acts of piracy or armed robbery at sea."); S.C. Res. 1918, supra note 10 (stating that the failure to prosecute those responsible for piracy and armed robbery at sea was undermining the international community's antipiracy efforts).

116. Lang Report, supra note 7, $942-43$.

117. Id. $₫ 14$.

118. Deterrence and the prevention of future criminal activity are primary goals of criminal prosecutions, including international criminal prosecutions. The Preamble to the Rome Statute creating the International Criminal Court, for example, emphasizes the potential deterrent effect of the court, noting that it is being created "to put an end to impunity for the perpetrators of [the covered] crimes and thus to contribute to the prevention of such crimes." United Nations Diplomatic Conference of Pleripotentiaries on the Establishment of an International Criminal Court, June 15-July 17, 1998, Rome, It., Rome Statute of the International Criminal Court, pmbl., U.N. Doc. A/CONF.183/9 (July 17, 1998) [hereinafter Rome Statute], available at http://www.icc-cpi.int/NR/rdonlyres/EA9AEFF7-5752-4F84-BE940A655EB30E16/0/Rome_Statute_\%20English.pdf; see also M. Cherif Bassiouni, Combating Impunity for International Crimes, 71 U. COLO. L. REV. 409, 410 (2000) ("The pursuit of justice and accountability, it is believed, fulfills fundamental human values, helps achieve peace and reconciliation, and contributes to the prevention and deterrence of future conflicts.'); Michael P. Scharf, The Prosecutor v. Dusko Tadic: An Appraisal of the First International War Crimes Trial Since Nuremberg, 60 ALB. L. REv. 861, 868 (1997) (quoting Richard Goldstone for the idea that international criminal tribunals will provide an enforcement mechanism to punish those who commit atrocities, thereby aiding in deterring future atrocities).

119. See, e.g., S/2010/394 Report, supra note 7, 甲9 19-23; see also Kontorovich \& Art, supra note 2, at 445 (showing in Table 3 that the navies capturing pirates on the high seas during 2008 and 2009 typically transferred the pirates to Kenya for prosecution).

120. S/2010/394 Report, supra note 7, Фণ 19-23.

121. Kontorovich \& Art, supra note 2, at $444-45$ \& tbl.3. 
that same period, Russia transferred ten captured suspected pirates to Yemen to stand trial. ${ }^{122}$ But, the evidence also suggests these transferee nations do not want to shoulder the entire burden of prosecuting and imprisoning pirates. Kenya, for example, has already complained that it does not want to be a "dumping ground" for pirates. ${ }^{123}$

It is also true that some of the states contributing to the antipiracy naval patrols have brought captured pirates back to their country to stand trial, rather than transferring those pirates to Kenya or some other African nation. The Netherlands prosecuted five Somali pirates who attacked a Dutch Antilles-flagged ship. In June 2010, those five were found guilty of sea robbery. ${ }^{124}$ France brought charges against several more suspects accused of committing piracy. ${ }^{125}$ The United States has previously prosecuted, and is currently prosecuting, a number of piracy suspects. ${ }^{126}$ Germany has also commenced at least one piracy prosecution in recent years. ${ }^{127}$ In addition, reports indicate

122. Id.

123. See Alphonce Shiundu, AG Queried over Kenya's Role on Piracy Cases, DAILY NATION (Mar. 30, 2010), http://www.nation.co.ke/News/AG\%20queried\%20over\%20Kenya \%20role\%20in\%20piracy\%20cases/-/1056/889516/-/196m63/-/index.html. Some reports also indicate that Kenya may refuse to accept any more suspected pirates for prosecution. See, e.g., Jeff Davis, Kenya: Country Cancels Piracy Trial Deals, All AfricA (Sept. 30, 2010), http://allafrica.com/stories/201010010009.html (reporting that Kenya had terminated agreements committing to try captured pirates in its courts); Lillian Leposo, Kenya Ends Agreement with EU To Prosecute Suspected Somali Pirates, CNN (Oct. 4, 2010), http:// articles.cnn.com/2010-10-04/world/Kenya.eu.pirates_1_somali-pirates-kenyan-authorities-Kenya-sministry?_s=PM:WORLD (same).

124. See Toby Sterling, Dutch Court Sentences 5 Somali Pirates to 5 Years, WASH. TIMES (June 17, 2010), http://www.washingtontimes.com/news/2010/jun/17/dutch-courtsentences-5-somali-pirates-5-years/?page=all.

125. See 6 Somali Pirates Arrive in Paris for Trial, USA TodAY (Apr. 16, 2008), http://www.usatoday.com/news/world/2008-04-16-france-pirates_N.htm.

126. See, e.g., United States v. Hasan, No. 100-CR-56 (E.D. Va. filed Apr. 21, 2010) (charging accused, inter alia, with attacking the USS NICHOLAS on the high seas); United States v. Saciid (aka Mohammed Said), No. 110-CR-57 (E.D. Va. filed Apr. 21, 2010) (charging accused, inter alia, with attacking the USS ASHLAND on the high seas); Patricia Hurtado \& David Glovin, Somali Pirate Captured by U.S. Pleads Guilty in Manhattan Federal Court, BloOMBERG (May 18, 2010), http://www.bloomberg.com/news/2010-05-19/Somalipirate-captured-by-U-S-pleads-guilty-in-manhattan-federal-court.html (reporting that the first pirate prosecuted by the United States in more than a century pled guilty to participating in hijacking the MAERSK ALABAMA and holding its American captain hostage off the coast of Somalia). In 2011, the United States brought charges against some additional alleged pirates. See, e.g., Brock Vergakis, 14 Indicted in Pirate Attack on American Yacht, WASH. TIMES (Mar. 10, 2011), http://www.washingtontimes.com/news/2011/mar/10/14-indictedpirate-attack-american-yacht/ (stating that fourteen suspected pirates had been indicted in the Eastern District of Virginia for participating in the attack on an American Yacht in February 2011 near Oman that left four Americans dead).

127. See, e.g., Matthias Gebauer, Horand Knaup, \& Marcel Rosenbach, Caught RedHanded: First Trial of Somali Pirates Poses Headache for Germany, DER SPIEGEL (Apr. 20, 
that Spain is prosecuting two suspected pirates, and Belgium is prosecuting one. ${ }^{128}$

Nevertheless, in the instances where the various nonregional states with patrolling navies have undertaken to prosecute piracy suspects, they appear to have done so only where they have a very direct and personal interest in the attack. For example, Germany charged Somali suspects with piracy based on acts committed 530 nautical miles east of the Horn of Africa against a German cargo ship. ${ }^{129}$ On the other hand, Germany has refused to take legal action in cases where no similar national interests were involved and has instead released the captured pirates. ${ }^{130}$ While the United States, like Germany, can be commended for bringing piracy charges against suspects captured off the coast of Somalia, the cases in which it has acted have similarly involved nationals as victims. ${ }^{131}$ Indeed, at present, some countries' laws permit them to exercise jurisdiction over piracy cases only where the attack was carried out against a ship or citizen of that country. ${ }^{132}$ Thus, in 2009, the Danish navy released ten suspected and armed Somali pirates because - as discussed in more detail belowDenmark's national laws permit it to exercise jurisdiction over piracy only where a Danish citizen or ship is the direct victim of the attack. ${ }^{133}$

2010), http://www.spiegel.de/international/world/0,1518,689745,00.html; Germany Hears First Piracy Trial in 400 Years, TelEgRAPH (Nov. 22, 2010), http://www.telegraph.co. uk/news/worldnews/piracy/8152251/Germany-hears-first-piracy-trial-in-400-years.html.

128. See Lang Report, supra note 7, 942.

129. See Karin Matussek, Somalis Face Hamburg Court in First German Piracy Trial for Four Centuries, BloomBERG (Nov. 22, 2010), http://www.bloomberg.com/news/2010-1122/ten-somalis-are-tried-in-hamburg-court-over-indian-ocean-pirate-attack.html.

130. Kraska \& Wilson, supra note 2, at 282 n.219 (citing German Navy Foils Somali Pirates, BBC News (Dec. 25, 2008), http://news.bbc.co.uk/2/hi/7799796.stm, wherein Commander Achim Winkler stated that Germany would only charge pirates where they had directly attacked German interests).

131. For information about the piracy cases in the United States, see sources cited supra note 126.

132. See infra Parts IV.D-E.

133. See Oliver Hawkins, What To Do with a Captured Pirate, BBC NEws (Mar. 10, 2009), http://news.bbc.co.uk/2/hi/7932205.stm. Other prosecutions in Western nations similarly involve some direct relationship between the state and the pirate attack. For example, a case in the Netherlands concerned the attempted capture of a cargo ship registered in the Dutch Antilles. See Adam Gabbatt, Piracy Trial Starts in the Netherlands, GuARDIAN (May 25, 2010), http://www.guardian.co.uk/world/2010/may/25/somalis-piracy-trial-nether lands. A recent piracy case in Madrid, Spain, involved two Somali pirates who had seized a Spanish fishing boat. See Spain Sentences Somali Pirates to 439 Years' Jail Each, BBC NEws (May 3, 2011), http://www.bbc.co.uk/news/world-europe-13272669. In addition, pirates brought to France for trial had attacked a French yacht. See supra note 125 and accompanying text. In Belgium, a Somali pirate faces trial for having hijacked a Belgian vessel off the Somali Coast. See Pirate To Face Trial in Belgium: Defence Ministry, AGENCE 
Germany, the United States, Denmark, and other Western states have apparently made decisions to release, rather than prosecute, captured pirates even though piracy is a universal jurisdiction crime and even though most states are parties to UNCLOS and the SUA Convention. ${ }^{134}$

In fact, it seems that states have used universal jurisdiction to prosecute acts of piracy very infrequently, even though universal jurisdiction over piracy has existed for hundreds of years. ${ }^{135}$ According to a recent study, less than $1.5 \%$ of the 1158 reported piracy attacks in international waters between 1998 and 2009 resulted in a universal

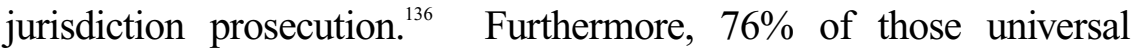
jurisdiction prosecutions were commenced in Kenya and involved alleged pirates captured by various Western patrolling navies. ${ }^{137}$ Only three other states (all non-Western) used universal jurisdiction during this time period to prosecute piracy offenses: China (two cases), India (one case), and Yemen (one case). ${ }^{138}$

Moreover, states are not using UNCLOS and the SUA Convention provisions with any regularity to prosecute acts of piracy. ${ }^{139}$ Even now when piracy attacks are increasing at an alarming rate, it appears that relatively few states have implemented domestic legislation incorporating these treaty provisions relating to the

FRANCE-PRESSE (Dec. 9, 2010), http://www.rnw.nl/africa/bulletin/pirate-face-trial-belgiumdefence-ministry.

134. For example, all EU member nations are members of UNCLOS and the SUA Convention, as are Australia, Canada, and New Zealand. The United States is a party to the earlier version of UNCLOS and a party to the SUA Convention. Chronological Lists of Ratifications of, Accessions and Successions to the Convention and Related Agreements as at 03 June 2011, supra note 34; see also Countries, EuROPA, http:/europa.eu/about-eu/countries/ index_en.htm (last visited Apr. 17, 2012) (listing Member States of the European Union).

135. See Eugene Kontorovich, The Piracy Analogy: Modern Universal Jurisdiction's Hollow Foundation, 45 HARV. INT'L L.J. 183, 192 (2004) (citing Alfred P. RuBIN, THE LAW OF PIRACY 302, 348 n.50 (2d ed. 1998)).

136. Kontorovich \& Art, supra note 2, at 444 . The authors note that they studied only responses to reported attacks, not actual attacks committed. Id. at 445.

137. Id. at $445,449$.

138. Id. at 447-49. The Yemen case involved proceedings against Somali defendants transferred by Russia's navy. Id. at 449 . Of course, nations may have commenced some piracy cases using universal jurisdiction since 2009 when the data set for this study ended. See id. at $444 \&$ n. 37.

139. See Eugene Kontorovich, "A Guantánamo on the Sea": The Difficulty of Prosecuting Pirates and Terrorists, 98 CALIF. L. REV. 243, 265 (2010) (stating that the SUA Convention has been used only once - in a case originally brought in the United States District Court for the District of Hawaii by the United States against a cook who commandeered a fishing trawler). For a record of the facts of that case, see United States v. Shi, 525 F.3d 709 (9th Cir. 2008). See also Carlo Tiribelli, Time To Update the 1988 Rome Convention for the Suppression of Unlawful Acts Against the Safety of Maritime Navigation, 8 OR. REV. INT'L L. 133, 136 (2006) (stating that UNCLOS has been used only once in a case against Greenpeace). 
repression of piracy into their domestic laws. ${ }^{140}$ Yet, under article 100 of UNCLOS, states agree to cooperate in the repression of piracy to the fullest possible extent. ${ }^{141}$ Under the SUA Convention provisions, signatory states in whose territory an offender is found must either extradite or prosecute. ${ }^{142}$

As discussed above, the Security Council's efforts to improve the results of the international community's antipiracy efforts have increasingly focused on this failure of states to criminalize piracy in their domestic criminal codes and their concomitant failure to accept their duty to prosecute and imprison pirates. ${ }^{143}$ The Security Council has called on all states to criminalize piracy under their national laws and also to consider favorably the prosecution of piracy suspects and the imprisonment of convicted pirates. ${ }^{144}$ In fact, by Resolution 1976, dated April 11, 2011, the Security Council expressly recognized that "piracy is a crime subject to universal jurisdiction" and reiterated its call on states "to favourably consider the prosecution of suspected, and the imprisonment of convicted, pirates apprehended off the coast of Somalia." 145 Mr. Lang similarly noted that piracy is a universal jurisdiction crime, and he urged all states to incorporate that basis for

140. See, e.g., Lang Report, supra note 7, १ฯ 46-47; Paulo Prada \& Alex Roth, On the Lawless Seas, It's Not Easy Putting Somali Pirates in the Dock, Wall St. J. (Dec. 12, 2008), http://online.wsj.com/article/SB122903542171799663.html (stating that few SUA Convention signatories had enacted domestic legislation permitting prosecution of foreigners for acts committed outside their territory); see also Report: The Role of the European Union in Combating Piracy, supra note 58, at 13 (stating that few states have incorporated the UNCLOS piracy provisions into their national laws).

141. UNCLOS, supra note 33, art. 100. The full text of article 100 provides: "All States shall cooperate to the fullest possible extent in the repression of piracy on the high seas or in any other place outside the jurisdiction of any State." According to the drafters' commentary written in connection with the identical provision contained in the earlier version of the Convention, "Any State having an opportunity of taking measures against piracy, and neglecting to do so, would be failing in a duty laid upon it by international law." See Report of the International Law Commission to the General Assembly, 11 U.N. GAOR Supp. No. 9, at 27, U.N. Doc. A/3159(SUPP) (1956), reprinted in [1956] 2 Y.B. Int'l L. Comm'n 265, U.N. Doc. A/CN.4/SER.A/1956/add.1.

142. See SUA Convention, supra note 33, arts. 7, 10.

143. See, e.g., S.C. Res. 1976, ๆๆ 13-14, U.N. Doc. S/RES/1976 (Apr. 11, 2011); see also Press Release, Security Council, Security Council, Unanimously Adopting Resolution 1918 (2010), Calls on All States To Criminalize Piracy Under National Laws, U.N. Press Release SC/9913 (Apr. 27, 2010), available at http:www.un.org/News/Press/docs/2010/ sc9913.doc.htm; S.C. Res. 1918, supra note 10, ๆ 2; S.C. Res. 1950, supra note 11, ๆף 12-13, 19.

144. See S.C. Res. 1976, supra note 143, Ф甲 13-14.

145. Id. $₫ 14$. 
prosecuting acts of piracy into their own criminal codes, and then to use those laws to prosecute pirates effectively. ${ }^{146}$

This Article echoes the Security Council resolutions and the other calls to states to criminalize universal jurisdiction over piracy in their own domestic criminal codes and then use those laws to prosecute acts of piracy, even when they may have no direct interest in the particular pirate attack. But, even if states pass piracy laws, the laws they pass must be sufficient to allow for a successful prosecution of today's pirates given the nature of their acts and where they commit those acts. To that end, in Part IV below, this Article surveys the types of domestic laws states have implemented to prosecute piracy offenses. Part V then analyzes those laws and discusses whether they are adequate to ensure that modern pirates can be successfully prosecuted.

\section{NATIONAl LAws CRIMINALIZING ACTS OF PiRACY: AN OVERVIEW}

I primarily gathered information about states' piracy laws from the information collected on the United Nations Division for Ocean Affairs and the Law of the Sea (UNDOALOS) Web site. ${ }^{147}$ Using information from this Web site offers several advantages. First, the information has been provided by states themselves in response to a request for information about their piracy laws, thus creating certainty about which precise laws the state believes it can use to prosecute piracy offenses. In fact, if anything, reporting states likely have reasons to overstate their ability to prosecute piracy offenses because they may want to show that they will be able to cooperate to repress piracy in conformance with the goals of customary international law, UNCLOS, and the SUA Convention. Thus, at least up to the date of the responses, there is reason to take at face value a state's representation that it has no domestic legislation authorizing the exercise of universal jurisdiction over piracy offenses. Similarly, there is reason to take as conclusive a state's representation that only some of its laws are available to prosecute piracy offenses. In addition, the information contained on the Web site has the benefit of being quite recent because it was supplied in response to the IMO Circular Letter dated December 23, 2008..$^{148}$

146. Lang Report, supra note 7, 9 - 48-51.

147. National Legislation on Piracy, supra note 15.

148. See IMO Circular Letter, supra note 15. 
Of course, the UNDOALOS Web site information has its limitations as well. The Web site contains responses from only some states, and fourteen of those responses are in languages other than English. ${ }^{149}$ Additional research did reveal another ten states with piracy laws available in English. ${ }^{150}$ Nevertheless, this means that the total number of states' laws that will be analyzed is approximately fifty. ${ }^{151}$

Even with these limitations, however, analysis of these laws provides significant and important information relevant to the questions posed in Part I about whether states have enacted domestic universal jurisdiction antipiracy laws and whether state laws are sufficient to ensure that modern pirates can be brought to justice. In fact, the analysis shows that few states have enacted comprehensive laws allowing them to exercise universal jurisdiction over piracy. It is true that language barriers and other difficulties associated with researching foreign laws necessarily means that some other states may have comprehensive antipiracy laws. Some states are also apparently in the process of amending their laws. ${ }^{152}$ However, given the many Security Council statements about the overall lack of domestic piracy laws, this sample containing about one quarter of all states is likely representative and supports a conclusion that only a fraction of all states has enacted laws consistent with the international legal framework governing maritime piracy. In any event, the laws that are the subject of this study vary greatly in terms of how they define piracy and what jurisdictional requirements must be met in order for the state to prosecute captured pirates. Accordingly, different types of laws can be analyzed and discussed, particularly as to whether states

149. The following states replied to the request for information in languages other than English: Bahrain, Chile, Cuba, Guatemala, Mexico, Peru, Spain, Uruguay, Belgium, Comoros, Morocco, Togo, and The Netherlands. See National Legislation on Piracy, supra note 15 .

150. Those states are Albania, Canada, Estonia, France, Georgia, Germany, Malaysia, Mauritius, Sweden, and the United Kingdom.

151. Several states responding to the IMO Circular Letter are included in the sample, but are not included in any particular category of state laws described below. For example, Grenada reported only that it had no legislation related to piracy. As to Zambia, the Philippines, and Argentina, this author could not conclude from the submissions the precise laws that govern piracy. Indeed, Zambia's response contained only excerpts of its AntiTerrorism Act of 2007, which seemed to address terrorism, rather than piracy. See id.

152. India is one of the states apparently in the process of amending its piracy laws. See Anti-Piracy: New Bill To Give Navy, Coast Guard More Powers, DAILY News \& ANALYSIS (June 28, 2011), http://www.dnaindia.com/india/report_anti-piracy-new-bill-togive-navy-coast-guard-more-powers_1560195. According to the Lang Report, Belgium, France, Japan, Maldives, Seychelles, and the Republic of Tanzania have begun the process of legislative reform in order to ensure their criminal laws are adequate to combat piracy. Lang Report, supra note 7, $\mid 47$. 
can exercise universal jurisdiction over piracy offenses so as to obviate the "necessity" of releasing pirates where the capturing state has no direct nexus to the offense.

Below, I describe the laws of states in the survey sample, organizing them into the following categories: (1) states defining piracy with reference to the law of nations (many of which also provide for universal jurisdiction (UJ)), (2) states purporting to have universal jurisdiction over piracy by incorporating international treaty commitments into their national laws, (3) states that specifically define piracy - according to UNCLOS's definition or otherwise - and that also have a framework providing for the exercise of universal jurisdiction, (4) states that specifically define piracy without a framework providing for universal jurisdiction over the offense, and (5) states that rely only on general domestic criminal laws without specifically defining piracy. ${ }^{153}$ The Table below shows the states that are in each category.

Table 2: States Included in the Survey Sample

\begin{tabular}{|l|l|}
\hline \multicolumn{1}{|c|}{ Type of Law } & \multicolumn{1}{c|}{ States } \\
\hline Law of Nations (some with UJ) & $\begin{array}{l}\text { US, New Zealand, Canada, Singapore, } \\
\text { Malaysia, Israel, Bahamas }\end{array}$ \\
\hline $\begin{array}{l}\text { Incorporating Treaty Commitments } \\
\text { (with UJ) }\end{array}$ & $\begin{array}{l}\text { Bulgaria, Poland, Finland, Oman, } \\
\text { Czech Republic, Iran, Latvia, China, } \\
\text { France }\end{array}$ \\
\hline UNCLOS (mostly with UJ) & $\begin{array}{l}\text { South Africa, Malta, UK, Kenya, } \\
\text { Tanzania, Cyprus, Liberia, Mauritius, } \\
\text { Australia }\end{array}$ \\
\hline $\begin{array}{l}\text { Defining Piracy without UNCLOS, } \\
\text { but with UJ }\end{array}$ & $\begin{array}{l}\text { Thailand, Japan, Greece, Estonia, } \\
\text { Ukraine, Germany }\end{array}$ \\
\hline Defining Piracy without UJ & $\begin{array}{l}\text { Sri Lanka, Denmark, Turkey, South } \\
\text { Korea, Georgia, Russia, Albania }\end{array}$ \\
\hline Other State Offenses & $\begin{array}{l}\text { Austria, Norway, Brazil, UAE, } \\
\text { Azerbaijan }\end{array}$ \\
\hline No Category & Grenada, Zambia, Argentina, \\
& Philippines \\
\hline
\end{tabular}

I do not specifically examine any state laws implementing the SUA Convention provisions because they do not allow states to exercise

153. Unless otherwise noted, I obtained the information about state piracy laws from the UNDOALOS Web site. The Web site lists the states that responded to the IMO Circular Letter and contains links to the letters, notes verbale, laws, or excerpts of laws that states submitted in response to that letter. See National Legislation on Piracy, supra note 15. To the extent that the UNDOALOS Web site is updated or changed in the future, copies of the information obtained from the Web site for this Article are on file with the author. 
universal jurisdiction over piracy offenses. ${ }^{154}$ Accordingly, the SUA Convention provisions cannot likely address the greatest apparent impunity gap, whereby states with no direct nexus to an offense capture pirates and thereafter release them, rather than prosecute them. Of course, states should still be encouraged to implement the SUA Convention's provisions as those provisions provide additional bases upon which states might be able to prosecute some acts that constitute piracy.

\section{A. States Defining Piracy According to the Law of Nations}

Several of the states in the sample define piracy according to the "law of nations," rather than specifically setting out the elements of the offense. For example, pursuant to 18 U.S.C. $§ 1651$, the United States provides universal jurisdiction over piracy and will sentence to life imprisonment "[w]hoever, on the high seas, commits the crime of piracy as defined by the law of nations, and is afterwards brought into or found in the United States." 155 New Zealand similarly provides for universal jurisdiction over "[p]iracy by the law of nations" on the high seas regardless of the nationality of the vessel or persons involved as perpetrators or victims of the offense. ${ }^{156}$ Canada, Singapore, and Malaysia have similar laws criminalizing piracy according to the law of nations, although unlike the United States, they do not necessarily provide for universal jurisdiction over the crime. ${ }^{157}$ In fact, Malaysia

154. See supra Part II.C.

155. 18 U.S.C. $\S 1651$ (2006).

156. See New Zealand's Response to IMO Circular Letter (citing Crimes Act 1961, section 92 (N.Z.) (internal quotation marks omitted)), available at http://www.un.org/depts/ los/LEGISLATIONANDTREATIES/PDFFILES/NZN_crimes_act_1961.pdf.

157. See, e.g., Criminal Code, R.S.C. 1985, c. C-46, § 74 (Can.); PenAl CodE $\S 130 \mathrm{~B}$ (Sing.). At the same time, however, Singapore's laws have additional specific provisions under Maritime Offences Act $\S 170 \mathrm{~B}(3-10)$ that could cover piracy offenses and that may provide for the exercise of universal jurisdiction. Israel and The Bahamas do not reference the law of nations in their legislation, although they similarly define piracy broadly without any reference to specific elements of an offense. Section 169 of Israel's Penal Law criminalizes piracy as follows: "A person who commits piracy or any act connected with or akin to piracy is liable to imprisonment for twenty years." See Letter from the Permanent Mission of Israel in Response to the IMO Circular Letter (Feb. 22, 2010) (citing Penal Law, 5737-1977, [Special Volume] LSI54 (1977) (Isr.)), available at http://www.un.org/depts/los/ LEGISLATIONANDTREATIES/PDFFILES/ISR_anti_piracy.pdf. In addition, Chapter 84 of The Bahamas Penal Code provides: "Whoever is guilty of piracy, or of any crime connected with or relating or akin to piracy, shall be liable to be tried and punished according to the law of England for the time being in force." Letter from the Bahamas in Response to the IMO Circular Letter (citing Penal Code, ch. 84, § 404 (Bah.)), available at http://www.un. org/depts/los/LEGISLATIONANDTREATIES/PDFFILES/BHS_penal_code.pdf. 
requires a nexus between the state and the offense before it will prosecute piracy according to the law of nations. ${ }^{158}$

\section{B. States That Directly Incorporate International Treaty Commitments}

Some states, however, do not reference piracy at all in their domestic legislation (much less specifically define the elements of the offense), but they have indicated that piracy should be an offense over which they can exercise universal jurisdiction because they follow a monist tradition, which allows for the direct incorporation of treaties to which the state is a party. For example, in its February 16, 2010, letter to the United Nations, Bulgaria explained that it has no specific universal jurisdiction antipiracy legislation. Rather, Bulgaria noted that it is a party to UNCLOS and that the country's Penal Code recognizes the concept of universal jurisdiction in that it applies to crimes committed by foreign nationals abroad where allowed by an international agreement to which the country is a party. ${ }^{159}$ Poland made a similar point in its letter to the United Nations, stating that Poland is a party to UNCLOS and the SUA Convention and that according to the country's constitution, those agreements constitute a part of the domestic legal order that may be applied directly. ${ }^{160}$

Other states that responded to the IMO Circular Letter similarly indicated - either by letter, note, or by the text of domestic legislation - that they have no specific piracy laws allowing for the exercise of universal jurisdiction, but that their treaty obligations have become part of their domestic laws. ${ }^{161}$ In addition, research revealed

158. According to section 22 of the Malaysia Courts of Judicature Act 1964, the High Court will have jurisdiction to try crimes committed by any "person on the high seas where the offence is piracy by the law of nations." Courts of Judicature Act 1964, § 22 (Malay.). That court will have jurisdiction over offenses committed within Malaysia's territory, onboard a Malaysia-flagged vessel on the high seas, or by any Malaysia citizen or resident on the high seas.

159. Letter from Permanent Mission of The Republic of Bulgaria in Response to the IMO Circular Letter (Feb. 16, 2010), available at http://www.un.org/depts/los/LEGISLA TIONANDTREATIES/PDFFILES/BGR_penal_code.pdf.

160. Letter from Poland in Response to the IMO Circular Letter, available at http://www.un.org/depts/los/LEGISLATIONANDTREATIES/PDFFILES/POL_penal_code. pdf.

161. For example, Finland explained in a verbal note that the "Finnish Criminal Code does not provide for 'acts of piracy' as specific offences," but that the criminal law can be applied on the basis of universal jurisdiction, including for offenses that would be considered piracy within the meaning of UNCLOS. Letter from Finland in Response to the IMO Circular Letter (Feb. 19, 2010), available at http://www.un.org/depts/los/LEGISLATIONAND TREATIES/PDFFILES/FIN_criminal_code.pdf. Oman stated that it has a crime punishing 
several other states' criminal codes that seem to contain no reference to piracy as a specific offense, but which contain provisions allowing for the exercise of universal jurisdiction over crimes committed by foreign nationals abroad where permitted by an international treaty to which the country is a party ${ }^{162}$

\section{States Defining Piracy as a Separate Offense with a Framework for Exercising Universal Jurisdiction}

Fifteen states in the sample define piracy (or sometimes, ship hijacking) as a separate offense and include some framework that seems to allow for the exercise of universal jurisdiction over the offense. Some have done so by specifically implementing the UNCLOS definition of piracy into their domestic legislationalthough some have tracked the language more rigorously than others. Other states, however, do not track UNCLOS's definition of piracy, but

assaults on vessels at sea, noted that it is a party to UNCLOS and the SUA Convention, and that those treaties are "in the position of the National laws of Oman." Letter from Oman in Response to the IMO Circular Letter (on file with author). The Czech Republic also advised that it has no specific piracy offense authorizing the exercise of universal jurisdiction, but that under section 9 of the Criminal Code, Czech law will also apply "in cases stipulated in a promulgated international treaty which is part of the legal order." Letter from Czech Republic in Response to IMO Circular Letter (citing Trestní zákon č. 40/2009 Sb. (Czech)), available at http://www.un.org/depts/los/LEGISLATIONANDTREATIES/PDFFILES/CZE_ criminal_code_2010.pdf. Iran stated that it has no specific piracy provision that tracks UNCLOS or the SUA Convention, but that persons committing acts that could be regarded as "piracy" under customary international law can be convicted under article 653 of the Islamic Punishment Act. Letter from Iran in Response to the IMO Circular Letter, available at http://www.un.org/depts/los/LEGISLATIONANDTREATIES/PDFFILES/IRN_national_legi slation.pdf. Latvia apparently has no specific piracy offenses authorizing the exercise of universal jurisdiction, but section 4(4) of its Code provides for jurisdiction over aliens who have committed crimes in the territory of other states where allowed by international agreements to which Latvia is a party. Letter from the Republic of Latvia in Response to the IMO Circular Letter, available at http://www.un.org/depts/los/LEGISLATIONAND TREATIES/PDFFILES/LVA_national_legislation.pdf.

162. For example, China's Criminal Code is apparently applicable to crimes stipulated in international treaties to which China is a party even though that Code contains no specific piracy provision. See, e.g., [Criminal Law] (promulgated by the Second Session of the Fifth Nat'l People's Cong., July 1, 1979) art. 9 (China), available at http://www.china.org.cn/ english/government/207319.htm (stating that China's criminal law is applicable to crimes stipulated in international treaties to which China is a party); Zou Keyuan, Enforcing the Law of Piracy in the South China Sea, 31 J. MAR. L. \& COM. 107, 114-15 \& nn.37-38 (2000) (stating that China's criminal law contains no specific provision on piracy, but that article 9 of the Criminal Law creates jurisdiction over crimes in international treaties to which China is a party).

Although France has a law prohibiting ship hijacking, it has no specific piracy crime. However, article 113-12 of the French Code Pénal states that "French Criminal law is applicable to offences committed beyond territorial waters, when international conventions and the law provide for this." CODE PÉNAL [C. PÉN.] art. 113-12 (Fr.). 
they nevertheless specifically define the elements of the offense of piracy to which universal jurisdiction applies.

\section{States with Laws That at Least Partially Implement UNCLOS's Piracy Provisions}

First, some states' domestic criminal laws, such as those of South Africa, Malta, and the United Kingdom, fully incorporate the definition of piracy contained in article 101 of UNCLOS, as well as its jurisdictional framework providing for the exercise of universal jurisdiction over acts of piracy committed on the high seas outside of the state's territory. ${ }^{163}$ Kenya's and Tanzania's laws also track UNCLOS's piracy provisions, though both omit the words "on the high seas" from section 101(a)(i). They instead include only, in section 101(a)(ii), UNCLOS's words, "outside the jurisdiction of any State."164 Cyprus also tracks UNCLOS's piracy definition, but instead of using UNCLOS's words "outside the jurisdiction of any State" in section 101(a)(ii) ${ }^{165}$ Cyprus uses the words "within or outside the jurisdiction of the Republic of Cyprus." ${ }^{\prime 166}$

Several other states incorporate UNCLOS's language into their domestic laws criminalizing piracy and also provide for the exercise of

163. See Criminal Code art. 328N (Malta); Defence Act of 2002 art. 24 (S. Afr.); Merchant Shipping and Maritime Security Act, 1997, c. 28, art. 101 (Eng.). In its Merchant Shipping Bill of 2006, Mauritius also tracks UNCLOS's piracy definition precisely in section 211. MERChANT ShIPPING BILl $\S 211$ (Mauritius). However, it also contains a jurisdictional provision in section 216 stating that courts will have jurisdiction over acts committed on vessels in the state's territory, where the person committing the acts is a citizen, and where the acts are committed by a foreign national on board a Mauritius ship on the high seas. Id. $\S 216$. Thus, it may be that despite the language implementing UNCLOS's piracy provisions, Mauritius still requires a nexus to the offense in order to prosecute. See id.

164. Section 369 of Kenya's Merchant Shipping Act of 2009 states in pertinent part that piracy means

(a) any act of violence or detention, or any act of depredation, committed for private ends by the crew or the passengers of a private ship or a private aircraft, and directed-

(i) against another ship or aircraft, or against persons or property on board such ship or aircraft; or

(ii) against a ship, aircraft, persons or property in a place outside the jurisdiction of any State.

The Merchant Shipping Act, (2009) Cap. $16 \S 369$ (Kenya); see also Merchant Shipping Act, 2003, No. 21, § 341 (Tanz.).

165. UNCLOS, supra note 33, art. 101(a)(ii).

166. Compare Letter from Cyprus in Response to the IMO Circular Letter (citing CRIMINAL CODE $§ 69$ (Cyprus)), available at http://www.un.org/depts/los/LEGISLATION ANDTREATIES/STATEFILES/CYP.htm\#piracy, with UNCLOS, supra note 33, art. 101(a)(ii). 
universal jurisdiction, although they omit some parts of the UNCLOS piracy definition. For example, Liberia does not include the language in article 101(b) of UNCLOS regarding "voluntary participation in the operation of a ship ... with knowledge of facts making it a pirate ship" or in article 101(c) regarding "any act of inciting or of intentionally facilitating an act." ${ }^{167}$ Australia's laws tracking UNCLOS's piracy definition similarly omit article 101(c)'s language about "inciting or of intentionally facilitating an act," although the country does include within its definition of piracy "voluntarily participat[ion] in the operation of a pirate-controlled ship.", 168

\section{States with Laws That Define Piracy Without Following UNCLOS's Definition}

Some other states do not specifically follow UNCLOS's piracy definition; however, they seem to include an offense specifically defining piracy (or in some instances, ship hijacking) and also provide for the exercise of universal jurisdiction over those offenses. For example, section 4 of Thailand's Antipiracy Law defines piracy as an offense that includes a number of acts, including (1) seizing or taking control over any ships by force, (2) destroying the ship, (3) detaining or confining persons on ships, and (4) robbery committed on the high seas by a person on board a private ship against a person or property on board for the private ends of the offender. ${ }^{169}$ In section 27 of the Act, Thailand criminalizes attempts to do any of the above acts. ${ }^{170}$ Furthermore, section 28 of the Act provides for jurisdiction over any of these acts of piracy committed by persons outside of Thailand. ${ }^{171}$ Although Japan only submitted a draft of its Antipiracy Measures Law in response to the IMO Circular Letter, that law defines piracy to include certain acts committed on the high seas or territorial waters or internal waters of Japan for private ends. The draft law also appears to

167. UNCLOS, supra note 33, art. 101(b)-(c). Accordingly, there is some question about whether Liberia is including attempted acts within its definition of piracy. Liberia does reference attempts under $\S 15.31(3)$, but only in connection with explaining what acts can constitute felonies of the first degree. The New Penal Law of 1976, § 15,31(3) (Liber.).

168. Compare Crimes Act 1914 (Cth.) ss 51-53 (Austl.), with UNCLOS, supra note 33, art. 101(c).

169. Letter from Thailand in Response to the IMO Circular Letter (citing ACT ON PREVENTION AND SUPPRESSION OF PIRACY, B.E. 2534 (1991) § 4 (Thai)), available at http://www.un.org/depts/los/piracy/piracy_national_legislation.htm.

170. Id. (citing ACT ON PREVENTION AND SUPPRESSION OF PIRACY, B.E. $2534 \S 27$ (Thai)).

171. Id. (citing ACT ON PREVENTION AND SUPPRESSION OF PIRACY, B.E. $2534 \S 28$ (Thai)). 
criminalize attempted piracy in that it includes within the piracy definition the acts of "preparing weapons and operating a ship for the purpose of committing" acts of piracy. ${ }^{172}$

Several other states also have laws that define the elements of the offense of piracy; however, they do not clearly include attempted acts within their piracy definition. In addition, although they reference the high seas in their piracy definition, they also seem to rely on other provisions in their criminal codes to authorize exercising universal jurisdiction over piracy. Specifically, Greece's submission in response to the IMO Circular Letter explained that article 215 of the Greek Code on Public Maritime Law defines piracy as acts "committed by anyone aboard a ship who, by using corporal violence or threat thereof against persons, commits acts of depredation against another ship on the high seas with the intention to take possession of objects so obtained." ${ }^{\prime 173}$ According to article 8 of the Greek Penal Code, national courts may exercise universal jurisdiction over acts of piracy irrespective of the nationality of the pirates. ${ }^{174}$ Submissions by Estonia and Ukraine are similar in defining piracy specifically and also in referring to other criminal code provisions that allow for the exercise of universal jurisdiction over the crime of piracy. ${ }^{175}$

172. Letter from Japan in Response to the IMO Circular Letter, available at http:// www.un.org/depts/los/LEGISLATIONANDTREATIES/PDFFILES/JPN_anti_piracy.pdf (submitting draft law on piracy).

173. Letter from Greece in Response to the IMO Circular Letter (citing [CODE OF PUBLIC MARITIME LAW] art. 215 (Greece)), available at http://www.un.org/depts/los/ LEGISLATIONANDTREATIES/PDFFILES/GRC_penal_code.pdf.

174. Id. (citing POINIKOS KODIAKAS [P.K.] [CRIMINAL CODE] 8 (Greece)).

175. Section 110 of the Estonia Penal Code defines piracy as "[a]ttacking, seizure or destruction of a ship" or "persons on board such ship, or seizure or destruction of property on such ship" that is "on the high seas or in a territory outside the jurisdiction of any state" and that under section 8, Estonia law applies internationally where the act is punishable under an international agreement to which Estonia is a party. Letter from Estonia in Response to the IMO Circular Letter (citing PENAL CODE $\S \S 8,110$ (Est.)), available at http://www.un.org/ depts/los/LEGISLATIONANDTREATIES/PDFFILES/EST_legislation_piracy.pdf. Article 446 of the Criminal Code of Ukraine 2001 defines piracy as "the use of a vessel, whether armed or not, for capturing any other sea or river vessel, and violence, robbery or any other hostile actions against the crew or passengers of such vessel, for the purpose of pecuniary compensation or any other personal benefits," and article 8 allows for jurisdiction over acts committed by foreign nationals "in such cases as provided for by the international treaties." Letter from Ukraine in Response to the IMO Circular Letter (citing CRIMINAL CODE OF UKRAINE art. 446 (Ukr.)), available at http://www.un.org/depts/los/LEGISLATIONAND TREATIES/PDFFILES/UKR_criminal_code.pdf. Italy's submission similarly indicated that it has criminalized piracy in articles 1135 and 1136 of the Italian Codice della navigazione (but apparently including no attempt provision), and its letter stated that a recent law of December 2008 provides that Italy has jurisdiction over those crimes committed on the high seas or in territorial waters by foreigners or nationals. Letter from Italy in Response to the IMO Circular Letter (citing arts. 1135-36 Codice della navigazione [C. nav.] (It.)), available at 
Finally, although it does not define piracy per se, section 316c of Germany's Criminal Code criminalizes assaults on sea traffic. According to section 6, that crime is listed along with genocide and others as one which Germany considers to be against internationally protected interests, such that German criminal law will apply even to acts committed abroad with which Germany has no national nexus. ${ }^{176}$

\section{States Defining Piracy Without a Framework for Exercising Universal Jurisdiction}

Another group of states in the sample has laws specifically defining the elements of a piracy offense; however, jurisdiction is limited to instances where the state has some territorial or national nexus to the offense. Indeed, for these states to exercise jurisdiction over acts of piracy occurring outside their own territorial waters, the offense must be committed on a ship flying the flag of that nation or be committed by or against a national. Thus, in none of these cases do the states' laws allow its courts to exercise jurisdiction over a pirate attack solely based on the nature of that offense.

For example, section 3 of Sri Lanka's Piracy Act, No. 9 of 2001, defines piracy as the taking or appropriating of any ship by means of theft, force, intimidation, deception, fraud, or other similar means. According to section 16 of the Act, however, the state may only prosecute such offenses committed outside Sri Lanka's territorial waters where the acts are committed by a citizen or against a ship registered in Sri Lanka. ${ }^{177}$ Denmark's Criminal Code also contains a provision in section 183a criminalizing piracy, which it generally defines as taking control of or interfering with the maneuvering of a ship by using unlawful coercion. As to acts occurring outside Denmark's territory, according to sections 6,7 , and $8 \mathrm{~b}$ of the code, however, Denmark requires a nexus between the offense and Denmark (for example, that the offense be committed on a Danish ship) in order to exercise jurisdiction. ${ }^{178}$

Turkey explained that it has a specific crime against hijacking sea vessels and that it extends jurisdiction to offenses committed on the

http://www.un.org/depts/los/LEGISLATIONANDTREATIES/PDFFILES/ITA_national_legi slation_piracy.pdf.

176. Strafgesetzbuch [StGB] [Penal Code], Nov. 13, 1998, Bundesgesetzblatt, Teil I [BGBI. I] 945, §§ 6, 316c (Ger.).

177. Piracy Act, No. 9 of 2001, § 16 (Sri Lanka).

178. Letter from Denmark in Response to the IMO Circular Letter (citing CRIMINAL CODE $\S \S 6-8,183$ (Den.)), available at http://www.un.org/depts/los/LEGISLATIONAND TREATIES/PDFFILES/DNK_national_legislation_piracy.pdf. 
high seas where its flagged vessels are attacked. ${ }^{179}$ Turkey also stated that the country can bring piracy or hijacking charges in connection with acts committed on foreign vessels, but generally will do so only where the victim is a Turkish citizen. Indeed, Turkey is not a party to UNCLOS, and its stated position is that "the responsibility for the prosecution of piracy-related offences should remain within the countries of the region." 180

\section{E. States Relying on General Criminal Laws Without a Framework for Exercising Universal Jurisdiction}

Finally, seven of the states in the sample do not address piracy as an independent and separate offense or attach to it any special jurisdictional framework. Rather, they treat piracy offenses as subsumed within general categories of crime such as robbery, kidnapping, assault, and murder and require a nexus between the state and the offense in order to prosecute the crime domestically.

For example, Austria's response to the IMO Circular Letter referred to the crimes enumerated in its Criminal Code-such as murder and deprivation of liberty — which it suggested could relate to

179. Letter from Turkey in Response to the IMO Circular Letter, available at http://www.un.org/depts/los/LEGISLATIONANDTREATIES/PDFFILES/TUR_penal_crimi nal_procedure.pdf.

180. Id.; see also Letter from South Korea in Response to the IMO Circular Letter, available at http://www.un.org/depts/los/LEGISLATIONANDTREATIES/PDFFILES/KOR_ legislation_piracy.pdf (noting that article 340 of the Criminal Act criminalizes piracy as the act of forcibly seizing a ship or taking another's property after intruding on a ship, but that pursuant to article 6 , South Korea only has jurisdiction over foreign nationals committing acts abroad if those acts are committed against South Korea or its citizens); CRIMINAL CODE art. 228, (Geor.), available at http://legislationline.org/documents/action/popup/id/16049/preview (showing that Georgia's Criminal Code contains laws prohibiting the illegal seizure or hijacking of a vessel and pirating (articles 227 and 228), but that as to crimes perpetrated abroad, jurisdiction appears limited to attacks against flagged ships (article 4) and in cases where the crimes were committed by citizens (article 5)); Letter from the Russian Federation in Response to the IMO Circular Letter, available at http://www.un.org/depts/los/LEGIS LATIONANDTREATIES/PDFFILES/RUS_national_legislation_piracy.pdf (referencing article 227 of the Russian Federation's Criminal legislation defining piracy as an assault against a vessel with intent to capture the property of others and with the use or threat of force, but not suggesting that the country had legislation to allow the exercise of universal jurisdiction over such offenses). Similarly, as to the crime of ship hijacking, section 7(e) of Albania's Criminal Code provides that to exercise jurisdiction over foreign nationals acting outside the territory of Albania, the act must have been against the interests of the Albanian state or an Albanian citizen. See Criminal Code of the Republic of Albania, Kodi Penal I Republikes Se Shoiperise [Criminal Code of the Republic of Albania] Nr. 7895, 27.1.1995, art. 7(e) \& 111 (Alb.). 
maritime piracy in some instances. ${ }^{181}$ However, Austria also indicated that it would require a nexus to the offense for it to exercise criminal jurisdiction over such crimes if committed on the high seas. Furthermore, even though Austria stated that Austrian criminal laws are applicable if an international treaty contains the obligation to prosecute, it noted it would require the approval of the competent Austrian authorities before it would prosecute foreign nationals for crimes committed on the high seas. And, of course, while article 100 of UNCLOS requires states to cooperate in the repression of piracy, it arguably does not contain an obligation to prosecute. ${ }^{182}$

Norway's correspondence from The Royal Ministry of Trade and Industry to the IMO dated September 25, 2009, sets out a regime similar to that of Austria's. ${ }^{183}$ While the country has laws punishing robbery generally, it has no specific provisions providing for universal jurisdiction over piracy. ${ }^{184}$ Norway does apply its criminal laws to acts occurring on Norwegian-flagged vessels on the high seas or abroad. However, Norway will only prosecute acts committed abroad by foreigners "after thorough consideration if the King (in council) so decides." 185 In general, Norway stated that prosecution in its country "should be reserved for cases where Norwegian investigation and prosecution would be comparatively advantageous compared to prosecution elsewhere." $" 186$

181. Letter from Austria in Response to the IMO Circular Letter (Feb. 8, 2010), available at http://www.un.org/depts/los/LEGISLATIONANDTREATIES/PDFFILES/AUT_ criminal_code.pdf.

182. UNCLOS, supra note 33, art. 100.

183. Letter from Norway in Response to the IMO Circular Letter (Sept. 25, 2009), available at $\mathrm{http} / /$ www.un.org/depts/los/LEGISLATIONANDTREATIES/PDFFILES/NOR_ piracy_summary.pdf.

184. Id.

185. Id.

186. Id:; see also Letter from Brazil in Response to the IMO Circular Letter, available at http://www.un.org/depts/los/LEGISLATIONANDTREATIES/PDFFILES/BRA_National_ Legislation.pdf (stating that Brazil has incorporated "armed robbery" in its domestic legislation as a criminal offense within Brazil's national jurisdiction, but with no other information); Letter from the United Arab Emirates in Response to the IMO Circular Letter (Mar. 1, 2010), available at http://www.un.org/depts/los/LEGISLATIONANDTREATIES/ PDFFILES/UAE_national_legislation.pdf (referencing several provisions in UAE's Commercial Maritime Law, including a law against conspiring against the safety of a shipmaster, sinking or inflicting life-threatening damage to a ship, and taking possession of a ship in an illegal way, but not suggesting that the country has legislation allowing it to exercise universal jurisdiction over such offenses); Letter from Azerbaijan in Response to the IMO Circular Letter (on file with author) (indicating that it had enacted domestic laws dealing with stealing a ship and sea robbery, but not suggesting that these crimes would be subject to universal jurisdiction). 


\section{AN ANALYSIS OF WHETHER THE VARIOUS TYPES OF National LaWs ARE SufFicient To SuCCESSFUlly Prosecute ACTS OF MOdERN PIRACY}

As is evident from the discussion above, states are not uniform in their domestic legal approaches to piracy. Some states provide for universal jurisdiction over piracy (even if they do not exercise that universal jurisdiction by prosecuting offenses that have no nexus to their state), but even then states use different language or methods to do so. Some states incorporate UNCLOS's provisions and specifically define the offense of piracy. Others incorporate none or only some of UNCLOS's language. Furthermore, even when they define the offense of piracy specifically, many states still require a nexus to the offense in order to prosecute. Not only is this lack of uniformity troubling, but many of the laws are inconsistent with the international legal framework governing piracy because they do not provide for the exercise of universal jurisdiction. In addition, many are likely insufficient in any event to ensure the successful prosecution of all acts that comprise modern piracy. ${ }^{187}$

\section{A. The Potential Difficulties with an Antipiracy Law That Refers Only to the Law of Nations}

As to those states that criminalize piracy according to the law of nations, as an initial matter, there is an obvious flaw in the laws that do not provide for universal jurisdiction. Without universal jurisdiction over piracy offenses, nations necessarily can only prosecute those offenses that directly affect them, thus leading to the "catch and release" practices of many navies. ${ }^{188}$

187. For many reasons, this analysis does not take into account how courts have interpreted or applied the state laws contained within this sample. Rather, the analysis generally takes state submissions in response to the IMO Circular Letter, and the language of those state laws, at face value when addressing the potential difficulties states may have in prosecuting modern piracy offenses.

188. Indeed, the November 2010 decision of the Mombasa High Court of Kenya shows that even where states attempt to prosecute pirates using universal jurisdiction, those pirates may still be released if a court finds that the state's laws do not have a clear provision allowing for the exercise of such jurisdiction over the crime of piracy, which in the Kenyan case was previously defined as "piracy jure gentium." See supra note 18 and accompanying text. Kenya's laws have now been amended and precisely define piracy based on the language of UNCLOS. Thus, the expectation is that its laws now allow the state to exercise universal jurisdiction over acts of piracy occurring on the high seas. However, as noted above, Kenya has also indicated that it does not want to shoulder the burden of prosecuting piracy cases alone. See Lang Report, supra note 7, $19150,72$. 
In addition, even where they provide for universal jurisdiction, laws that define piracy only according to the law of nations may not be specific enough to allow for the prosecution of certain acts that could constitute piracy. Under the principle of nullum crimen sine lege, no one can be held guilty because of an act or omission that was not defined as a criminal offense under national or international law at the time of the offense. ${ }^{189}$ More broadly, corollary legislative and interpretive principles require that criminal statutes be drafted with some specificity, be strictly construed, and that any ambiguities be resolved in favor of the accused. The purpose of these principles is to ensure the legality of criminal law so that individuals are on notice of proscribed conduct and are protected against arbitrary and oppressive state action. ${ }^{190}$

This is not to suggest that states may not define criminal conduct by reference to other laws, such as the law of nations. ${ }^{191}$ Indeed, states may do so, and the "law of nations" has generally become synonymous with the term "customary international law"- the law that results from a general and consistent practice of states, which they follow because of a sense of legal obligation. ${ }^{192}$ Determining the precise contours of that general and consistent practice as it relates to the definition of piracy or otherwise, however, can require courts to consult a variety of sources, including international treaties, international custom and principles, judicial decisions, and scholarly writings. $^{193}$ Although UNCLOS likely reflects the definition of universal jurisdiction piracy under modern customary international law, not all scholars or courts will necessarily agree with that assessment. ${ }^{194}$ Accordingly, because the "law of nations" language does not precisely define what conduct constitutes or comprises the offense of piracy, some pirates may go unpunished if a court concludes

189. This principle is often incorporated into international human rights treaties. See, e.g., Rome Statute, supra note 118, art. 22 ("A person shall not be criminally responsible under this Statute unless the conduct in question constitutes, at the time it takes place, a crime within the jurisdiction of the Court.").

190. Beth Van Schaak, Crimen Sine Lege: Judicial Lawmaking at the Intersection of Law and Morals, 97 GEO. L.J. 119 (2008).

191. See, e.g., United States v. Smith, 18 U.S. (5 Wheat.) 153, 158-62 (1820) (stating that defining general piracy according to the "law of nations" is a sufficiently clear and constitutional exercise of Congress's power to define and punish piracy).

192. See, e.g., Flores v. S. Peru Copper Corp., 414 F.3d 233, 248 (2d Cir. 2003).

193. E.g., United States v. Hasan, 747 F. Supp. 2d 599, 630-31 (E.D. Va. 2010).

194. See sources cited supra note 31; see also Hasan, 747 F. Supp. 2d at 640-42 (finding that the definition of piracy reflects the current state of customary international law for purposes of interpreting 18 U.S.C. $§ 1651$ (2006)). 
their acts are not included within the conduct proscribed-and for which they were on notice they may be punished. ${ }^{195}$

As mentioned in Part I, the Eastern District of Virginia's recent decision evidences what can happen when piracy is defined according to the law of nations, rather than by a statute that specifically sets out the elements of the offense. In United States $v$. Said, the court dismissed charges under 18 U.S.C. $§ 1651$, concluding that the "law of nations" piracy definition would not include the pirates' acts because they were captured before taking control of an American warship. ${ }^{196}$ In so concluding, the court noted that like all criminal statutes, $\S 1651$ is subject to the constitutional rigors of due process which demand that defendants be given fair warning of the charged conduct, such that courts will not enforce statutes that are vague in terms of the conduct proscribed or required. In addition, the court emphasized that criminal statutes are to be construed strictly and that any ambiguities must be resolved in the defendant's favor. After examining judicial opinions from the United States and several foreign sources for guidance, the court determined that the definition of piracy from international sources was not sufficiently clear and that based on United States precedent, piracy is defined as sea robbery, which requires an actual taking, rather than conduct that could amount to an attempt. ${ }^{197}$

One can, of course, debate the correctness of the court's conclusion. ${ }^{198}$ The decision nevertheless illustrates the difficulties a state may face in successfully prosecuting pirates where the state's law does not precisely define the elements of the offense - and in this case, does not include a provision stating that attempts or similar inchoate crimes like conspiracy also constitute the crime.

\section{B. The Potential Difficulties with National Laws That Incorporate International Treaties Without Specifically Defining the Offense of Piracy}

The national laws generally incorporating treaty law, rather than specifically and separately defining the offense of piracy according to that treaty law, have similar deficiencies with respect to ensuring that

195. Even if UNCLOS's piracy definition constitutes customary international law and also provides the definition of piracy pursuant to these "law of nations" statutes, prosecuting some acts of piracy using the UNCLOS definition may still prove difficult. I discuss these potential issues in more detail below in Part V.C.

196. 757 F. Supp. 2d 554, 566 (E.D. Va. 2010).

197. See id. at 556-58.

198. See sources cited supra note 21 . 
pirates will not escape justice. Theoretically, under the monist tradition followed by some civil law countries, international law is automatically incorporated into the domestic legal order without the need for some separate domestic legislation implementing treaty terms. ${ }^{199}$ Nevertheless, the very absence of domestic legislation defining the precise contours of the crime and its penalties renders it possible for defendants to argue that prosecuting them violates those legality principles requiring advance notice of the particular proscribed conduct that can be punished. Indeed, in the criminal context, direct application of treaty obligations may seem unfair, especially because requiring the state to implement those international obligations into its domestic laws would not impose a great burden. ${ }^{200}$

The facts of a case filed in Senegal in February 2000, relating to torture allegedly committed in Chad by its former dictator H. Habré before his government was overthrown in 1991, illustrate how failing to implement domestic legislation precisely defining and criminalizing treaty crimes can pose difficulties. The indictment charged Habré with complicity to commit torture and suggested that Senegal's commitment to the Convention Against Torture allowed the court to exercise universal jurisdiction over the alleged crimes. The defendant, however, moved to dismiss the charges against him. He argued, among other things, that Senegal's courts had no jurisdiction over crimes committed in Chad because although Senegal ratified the treaty in 1986, it did not actually implement legislation incorporating treaty crimes until 1996 - a date before which the alleged torture had been committed. The victims' lawyers, on the other hand, pointed out that under Senegal's constitution, international treaties are automatically incorporated into domestic law and have precedence over inconsistent aspects of that law. In its holding, the court agreed with the defense, concluding that even though Senegal followed a monist system, the Torture Convention could not be directly applied and that the absence of implementing legislation until after the alleged crimes had occurred meant that Senegal could not exercise extraterritorial jurisdiction over the offense. Among the justifications for its conclusion, the court explained that criminal law requires clarity and "formalism" beyond that required in other areas of the law. Therefore, the state could not

199. See AleXANDER Zahar \& Göran Sluiter, InTERnational Criminal LaW: A CRITICAL INTRODUCTION 491 (2008). Most common law countries follow the dualist tradition and do not recognize treaties as self-executing. See MARK WeStON JANIS, INTERNATIONAL LAW 100-02 (5th ed. 2008).

200. ZAHAR \& SLUITER, supra note 199, at 491. 
exercise universal jurisdiction over criminal offenses without implementing specific domestic legislation detailing the elements of the crime and the basis for the exercise of jurisdiction. ${ }^{201}$ The court's decision has been criticized for demonstrating bias, rather than the proper interpretation of Senegalese law. ${ }^{202}$ Nevertheless, had Senegal promptly and specifically implemented the Torture Convention provisions into its domestic law, the court may not have been able to find that the Senegalese courts were unable to exercise universal jurisdiction over acts of torture.

The In re Javor case in France similarly illustrates the problems that can arise when a state fails to implement specific domestic legislation incorporating treaty obligations. In Javor, the Court of Cassation concluded that the 1949 Geneva Conventions could not create a basis for French courts to exercise universal jurisdiction over criminal charges involving Bosnian victims of "ethnic cleansing" in Bosnia by their Serbian torturers. Although those Conventions had been ratified by France, the Supreme Court held they could have no direct effect on the country's domestic legislation because "their provisions have too general a character to be able directly to create rules on extraterritorial jurisdiction in criminal matters."203 Again, whether or not this decision was correct, like the Senegal court's decision, this decision also highlights the uncertainties associated with relying solely on direct incorporation of treaty obligations. ${ }^{204}$ Even for states that follow the monist tradition, implementing piracy provisions directly into their criminal laws seems the safest course and the one most likely to ensure that the state can exercise universal jurisdiction over piracy and share the burden in prosecuting pirates. There seems little reason — other than a lack of political will—not to specifically implement domestic legislation authorizing the exercise of universal

201. Reed Brody \& Helen Duffy, Prosecuting Torture Universally: Hissène Habré, Africa's Pinochet?, in InTERNATIONAL AND NATIONAL PROSECUTION OF CRIMES Under InTERnAtional LaW: CurRent DeVElopments 817-832 (Horst Fischer, Claus Kress \& Sascha Rolf Lüder eds., 2001).

202. Id. at 832-36; see also Chronology of the Habré Case, HuMAN Rights WATCH (Mar. 9, 2012), http://www.hrw.org/fr/node/80727 (explaining that the court's decision was strongly criticized by the Special Rapporteur on Torture, among others).

203. See Brigitte Stern, International Decisions, In re Javor, 93 AM. J. INT'L L. 525 (1999) (internal quotation marks omitted).

204. Brigitte Stern suggests that the Javor decision was incorrect and that under France's Code Pénal, France can exercise universal jurisdiction whenever an international convention - like the Geneva Conventions at issue - grants such jurisdiction. Id. at 528-29. She concludes that the Javor case and others illustrate the reluctance of the French courts to utilize universal jurisdiction. Id. at 529. 
jurisdiction over piracy offenses because doing so will necessarily eliminate at least some of the arguments captured pirates can make in an effort to escape justice.

\section{The Potential Difficulties with National Laws That Define Piracy According to UNCLOS}

Although UNCLOS's provisions allow states to exercise universal jurisdiction over piracy occurring on the high seas, the state law provisions surveyed that seem to implement UNCLOS's provisions will not necessarily be sufficient to ensure the successful prosecution of all pirates wherever captured and whatever the acts they have committed. First, laws that do not provide for the exercise of universal jurisdiction (such as those of Mauritius) have the evident flaw of requiring the state to have some nexus to the offense before it will prosecute. ${ }^{205}$ Again, unless states have domestic laws allowing them to prosecute piracy offenses even where they are not directly affected by the attack, the impunity gap will not be closed because states' navies will continue to release captured pirates.

Even with provisions allowing for the exercise of universal jurisdiction, however, laws that follow UNCLOS may not guarantee the successful prosecution of all piratical acts. First, states can only use UNCLOS as a basis for prosecuting piratical acts occurring on the high seas. On the other hand, even with this limitation, states with laws tracking UNCLOS's language will still have many opportunities to prosecute pirates. As noted above, numerous attacks are occurring far out to sea, and recent evidence suggests that piracy on the high seas - as opposed to armed robberies in territorial waters - represents an increasingly greater percentage of all global piracy incidents. ${ }^{206}$

In any event, where attacks occur within a state's own territorial waters, states can use laws other than those premised on UNCLOS to prosecute the offenders. The territorial state can prosecute attacks using domestic laws such as those governing robbery or assault. Of course, states like Somalia may not presently be capable of prosecuting acts of piracy occurring within their territorial waters. But, even then, other states may still be able to exercise jurisdiction. As long as states implement the SUA Convention provisions into their domestic laws, states with a nexus to the piracy offense will be able to exercise

205. See supra note 163 and accompanying text (noting that Mauritius's laws appear to require such a nexus to the offense to prosecute).

206. See sources cited supra note 54 . 
jurisdiction over acts of piracy occurring within the territorial waters of other states, provided the attacked ship is scheduled for international navigation. ${ }^{207}$ Accordingly, although states implementing UNCLOS's piracy provisions will not thereby be able to exercise universal jurisdiction over any and all pirate attacks, they will still be able to exercise such jurisdiction over the significant number of attacks on the high seas. Moreover, as long as states also implement the SUA Convention's provisions, they will have additional bases upon which to exercise jurisdiction over piracy offenses - even those occurring in the territorial waters of other states.

Second, UNCLOS's "private ends" language may also place some limitations on the type of acts that states can successfully prosecute. It is true that many commentators have suggested that the "private ends" language was meant only to preclude the prosecution of unrecognized insurgents acting solely against a foreign government and ships acting pursuant to public authority. ${ }^{208}$ However, as written, the language could be seized upon by pirates who may argue that "private ends" means acts directed toward obtaining a private gain, as opposed to acts motivated by some "cause." Therefore, even though they may have captured a ship and seized hostages, some pirates may argue that their acts are not piracy within the meaning of UNCLOS because their acts were not motivated for private gain. Pirates may be able to make a similar argument under the laws of Ukraine and Greece. Ukrainian laws define piracy to require that acts be committed "for the purpose of pecuniary compensation or any other personal benefits. ${ }^{209}$ Greece defines piracy to require that acts be committed "with the intention to take possession of objects so obtained."210 Of course, most pirates demanding millions of dollars in ransom for the safe return of passengers and crew will likely have a difficult time convincing a court that their acts were politically motivated, especially given the evidence showing that piracy is big business with pirate stock markets and with links to organized crime. ${ }^{211}$ Nevertheless, the risk that pirates will attempt to use the "private ends" or similar language to escape justice is reason for states to consider eliminating any reference to such a requirement - especially because many commentators have suggested that the language was not intended to be so limiting. At the very least,

207. See discussion supra Part II.C.

208. See sources cited supra notes 47-48.

209. See Criminal Code OF UKraine art. 446 (Ukr.).

210. See supra note 173 and accompanying text.

211. See sources cited supra notes 84-85. 
states should also implement the SUA Convention provisions, which contain no such language. ${ }^{212}$

Third, states that include UNCLOS's language requiring "two ships" within their piracy laws may also be unable to exercise universal jurisdiction over some acts that would seem to otherwise qualify as piracy. If the crime of piracy requires two ships, then pirates who board a victim ship at its last port and thereafter attack the ship's crew on the high seas may be able to argue that they did not commit piracy within the terms of the treaty. ${ }^{213}$ Again, so that states may exercise universal jurisdiction over the greatest possible range of pirate attacks, states should eliminate the "two ships" language and also implement the SUA Convention provisions, which do not contain limiting "two ships" language.

Fourth, in order to close the impunity gap associated with maritime piracy, states need to ensure that their laws at least track UNCLOS's language, which appears to include acts that are preparatory to an actual attack within the definition of piracy. In fact, the Lang Report recommends that states go beyond tracking UNCLOS's attempt language, which states that piracy includes "voluntary participation in the operation of a ship ... with knowledge of facts making it a pirate ship" or "any act of inciting or of intentionally facilitating an act [of piracy].",14 According to the Lang Report, states should instead take care to define precisely the elements of attempted piracy in order to avoid having a court conclude that the acts of certain captured pirates are insufficient to constitute an attempt. $^{215}$ Yet, as the survey of state piracy laws shows, even some of the states tracking UNCLOS have not included its language regarding attempts within their piracy definition. ${ }^{216}$ Other states that define piracy without tracking UNCLOS, such as Greece, Ukraine, and Estonia, also seem to omit attempts from the conduct included within their definition of piracy. But, all nations should want to ensure that they have laws authorizing the exercise of universal jurisdiction over

212. See discussion supra Part II.C.

213. See Milena Sterio, The Somali Piracy Problem: A Global Puzzle Necessitating a Global Solution, 59 AM. U. L. REV. 1449, 1468 (2010).

214. See UNCLOS, supra note 33, art. 101(b)-(c); see also Lang Report, supra note 7, ๑1 59.

215. See Lang Report, supra note 7, $₫ 59$.

216. For example, Liberia does not include the language in article 101(b) of UNCLOS regarding "voluntary participation in the operation of a ship ... with knowledge of facts making it a pirate ship" or in section 101(c) regarding "any act of inciting or of intentionally facilitating an act." Compare UNCLOS, supra note 33, art. 101(b)-(c), with The New Penal Law of 1976, supra note 167. 
pirates that are caught before they have attacked, held innocent seafarers hostage, and demanded ransom payments. If nations do not prosecute those pirates, and instead release them, the evidence suggests that the pirates will only keep trying until they are successful in reaching their criminal and monetary aims. ${ }^{217}$

\section{The Potential Difficulties with National Laws That Require a Nexus Between the State and the Offense}

Finally, the laws that require a nexus between the state and the offense in order for the state to prosecute piracy offenses are obviously inadequate to close the impunity gap surrounding maritime piracy. That states have not enacted laws providing for universal jurisdiction over piracy explains the prevalent "catch and release" practices where nations will not prosecute piracy offenses unless they have some very direct relationship to the attack. ${ }^{218}$ The evidence shows, however, that pirates are unlikely to be deterred from committing their increasingly frequent and violent attacks unless the world community as a whole steps up to prosecute pirates without regard to where the attacks were committed or what nationalities were involved in the attacks. ${ }^{219}$ Universal jurisdiction over piracy exists, and at the very least, states should implement UNCLOS's provisions allowing for the exercise of universal jurisdiction over piracy - although as noted above, the language of some of those provisions can be improved. The naval patrols to which the world community has committed substantial resources will not be completely successful in their antipiracy mission unless the world community also shares the burden of ensuring that the captured pirates are prosecuted and punished for their criminal acts.

\section{CONCLUSION}

This study has produced evidence of a problem in global governance as it relates to solving the problem of modern maritime piracy. Consistent with the various statements of the Security Council and other international actors, on the whole, it appears that state practices regarding piracy are inconsistent with the international legal framework that has defined piracy, labeled it as a problem, and provided tools to be used against those who attack innocent seafarers. The evidence shows that few states have enacted domestic legislation

217. See sources cited supra notes 114-115.

218. See discussion supra Part III.C.

219. See sources cited supra note 118. 
allowing them to exercise universal jurisdiction over piracy, notwithstanding that most are also parties to UNCLOS. Yet, the international community unanimously supported Security Council Resolutions authorizing antipiracy operations, while at the same time making statements about how piracy negatively and seriously affects the world community. ${ }^{220}$ Furthermore, the international community has spent billions of dollars to support naval operations aimed at repressing and deterring piracy.

It is true that states may have reasons to stand back and wait for others to carry the burden of maritime piracy prosecutions - or push that burden onto less developed and arguably less capable nations like Kenya. After all, piracy cases may result in asylum claims, can be costly, and can involve significant evidentiary difficulties. Also, given the relative newness of the modern piracy problem, states and their law enforcement institutions may not be comfortable bringing cases that could involve citizens from other states and evidence collected on the high seas thousands of miles away from the prosecuting states. Nor may states be comfortable trying to convince their domestic audiences that they should expend limited prosecutorial and judicial resources on cases that do not involve harm to its citizens. ${ }^{221}$ For all these reasons, and possibly others, states may conclude that they are better off not even passing laws allowing them to prosecute universal jurisdiction piracy cases.

But, given the increasing threat posed by piracy over the last several years, states should begin to see that their present response is insufficient and that there are reasons to embrace the international legal framework and the tools it provides for punishing and deterring piratical acts. In short, the time has come to think of the bigger international picture and put self-interest to the side. Most states are parties to UNCLOS and should, as a result, be required to abide by their duties under that treaty to cooperate to the fullest extent possible to repress piracy. Unless states start punishing pirates more regularly, the threat posed by piracy will only increase - with potential disastrous

220. See supra notes 103-109 and accompanying text. It is worth noting that those states supporting the Resolutions include states like Norway and Turkey who suggested in their responses to the IMO Circular Letter that they would prefer to prosecute piratical acts only where their own citizens were victims of the attacks.

221. See, e.g., Dutton, supra note 9, at 236 (discussing the potential threat of asylum claims as a reason why nations fail to prosecute pirates on their own soil); Kraska, supra note 84, at 207 (explaining the logistical and evidentiary difficulties associated with prosecuting pirates because the cases can involve suspects, victims, vessels, and witnesses from a number of countries). 
results for shippers and others who wish to use the world's shared sea lanes for commerce and pleasure. Moreover, developed nations in particular are well suited to handle the difficulties and costs associated with prosecuting piracy cases and should, accordingly, embrace their duty to share in the burden of prosecuting pirates.

In fact, developed nations have used universal jurisdiction to prosecute other types of crimes with which they have no connection, notwithstanding the potential asylum claims that may follow or the costs and evidentiary difficulties that may be involved. Furthermore, nations have exercised universal jurisdiction over some other types of crimes even though doing so may be politically controversialbecause, for example, the cases are commenced against the leaders or ex-leaders of another state. ${ }^{222}$ According to one report, between 1998 and 2008, European countries invoked the concept of universal jurisdiction in more than fifty cases that were commenced against defendants from a variety of countries, charging them with committing crimes such as murder, torture, war crimes, and genocide. ${ }^{223}$ Arguably, piracy offenses are different in nature from some other universal jurisdiction crimes like genocide. However, the evidence detailed above does show that pirate attacks involve some of the same violent acts that characterize many universal jurisdiction crimes. The evidence also shows that pirate attacks continue to threaten the safety of international sea lanes, the delivery of goods, and the safety of the environment-facts that should persuade states that prosecuting piracy using universal jurisdiction is warranted. ${ }^{224}$

Thus, developed nations have willingly exercised universal jurisdiction to pursue cases that, in many instances, must be politically controversial. Yet, they have begged off using universal jurisdiction to try pirates, even though doing so should not pose any real risk of diplomatic tensions between states. Indeed, there is no reason to expect that any state would argue that pirates should not be prosecuted or that they should be prosecuted by only their nation state. Somalia provides an example in this regard. Its temporary government does not argue that pirates should not be prosecuted, and it apparently welcomes the world community's assistance in eradicating the problems that

222. See, e.g., Kaleck, supra note 29, at 933-34 (explaining that the United States argued that Belgium's use of legislation allowing it to exercise jurisdiction over alleged crimes committed by ex-officials such as President George H.W. Bush threatens state sovereignty).

223. Kaleck, supra note 29, at 931-58.

224. See supra Part III.A. 
piracy is causing for Somalia and the world community as a whole. ${ }^{225}$ Furthermore, there is little reason to expect that states with no connection to a pirate attack will fight amongst themselves to take the case. Of course, one way to avoid any fighting between states over the right to prosecute is to agree that flag or victim states will have the first right to proceed. Should such states be unable or unwilling to prosecute, another nation could then invoke universal jurisdiction over the offense.

Piracy is a universal problem that harms the international community as a whole. ${ }^{226}$ Despite navies cooperating to capture pirates, in order for international cooperation regarding piracy to be effective in attaining the stated goal of repressing piracy, states must implement domestic universal jurisdiction antipiracy legislation. In addition, however, all states must show that they are willing to share in the burden of prosecuting and imprisoning pirates. As Mr. Lang has stated, less developed states are unlikely to continue to share in the burden of prosecuting and imprisoning pirates unless they see that wealthier states are also willing to mount prosecutions - and not just when their citizens are harmed. ${ }^{227}$

225. See S.C. Res. 1851, supra note 98, pmbl. (noting the requests from the Transitional Federal Government of Somalia for international assistance to counter piracy off its coast).

226. In an executive order dated April 12, 2010, President Obama stated that acts of piracy and armed robbery off the coast of Somalia posed an extraordinary threat to the national security and foreign policy interests of the United States. See Exec. Order No. 13,536, 75 Fed. Reg. 19,869 (Apr. 15, 2010); see also Exec. Notice, 76 Fed. Reg. 19,897 (Apr. 8, 2011) (continuing Executive Order 13,536 for one year); Fighting Piracy on Land and at Sea: Testimony to the U.S. House of Representatives, Foreign Affairs Subcommittee on International Organizations, Human Rights and Oversight, UNITED NATIONS OFF. ON DRUGS \& CRIME (May 14, 2009), http://www.unodc.org/unodc/en/about-unodc/speeches/ 2009-14-05.html (discussing the threat of Somali piracy to the stability of the region and the commercial and security interest of U.N. Member States).

227. Lang Report, supra note 7, ๆฯ 71-76. 